\title{
Development and calibration of a WDXRF routine applied to provenance studies on archaeological ceramics
}

\author{
Myrto Georgakopoulou ${ }^{1,2}$, Anno Hein ${ }^{3}$, Noémi S. Müller ${ }^{1}$, Evangelia Kiriatzi ${ }^{1}$ \\ ${ }^{1}$ Fitch Laboratory, British School at Athens, 52 Souedias Street, 10676 Athens, Greece. \\ ${ }^{2} U C L$ Qatar, PO Box 25256, Georgetown Building, Education City, Doha, Qatar. \\ ${ }^{3}$ Institute of Nanoscience and Nanotechnology, NCSR "Demokritos", 15310 Aghia Paraskevi, Greece.
}

\begin{abstract}
Elemental analysis of ancient ceramics is primarily used in provenance research, where defined compositional groups are attributed to particular raw materials sources or production locations. Requirements in data quality and analytical performance are high, as is the need for clear and reproducible methodologies, and the availability of information on the above to ensure interlaboratory comparability and long-term data validity. This paper outlines the measurement parameters of a dedicated calibration set-up for the analysis of ancient ceramics using wavelength-dispersive X-ray fluorescence spectrometry (WDXRF). The specimens are prepared as concentrated glass beads, allowing the measurement of 26 elements from a single sample, thus minimising sample size requirements. Certified and non-commercial standards are used to evaluate the performance of the method in terms of detection limits, precision, repeatability, and accuracy. The materials used cover a range of compositions in line with the matrix variability encountered in archaeological ceramics. The data confirm the high standard of the method and highlight specific limitations. An initial assessment of comparability with other set-ups used in ceramic analyses, primarily Neutron Activation Analysis, is given through a discussion of performance on commonly analysed materials. The advantages of the proposed method include excellent analytical performance, analysis of a large suite of elements including all major, minor and a good range of traces, relatively small sample sizes, and preparation of samples that can be stored and re-analysed.
\end{abstract}

\section{Keywords}

Archaeological ceramics, WDXRF, calibration, provenance

\section{Introduction}

Elemental (often referred to as chemical) bulk analysis is a powerful method for characterisation of archaeological ceramics. The results are used primarily in provenance studies, that is for the assignment of analysed pottery products to specific production locations and the reconstruction of past circulation patterns for ceramic products. A basic hypothesis for this approach is the 'Provenience Postulate', stating the assumption that the chemical variability among natural sources of raw materials, such as clays, or alternatively between different pottery assemblages, exceeds the variability within a given source or pottery assemblage from one production site ${ }^{[1]}$. As potters were using particular clays or clay mixes and potentially temper materials for the preparation of a specific clay paste the produced pottery would eventually present 
a distinct elemental and petrological composition. This composition can be related to a particular production place and a specific recipe that can be traced back to its original production location, even if the pottery had been traded over large distances.

The first attempts to examine the origin of archaeological ceramics on the basis of their elemental composition were implemented in the late 1950's using neutron activation analysis (NAA) ${ }^{[2]}$, X-Ray Fluorescence ${ }^{[3]}$ or optical emission spectroscopy $(\mathrm{OES})^{[4,5]}$. Since then the approach has been further developed and over the years a wide range of additional analytical methods have been employed, such as atomic absorption spectroscopy (AAS) ${ }^{[6,7]}$, inductively coupled plasma optical emission spectroscopy (ICP - OES) ${ }^{[8]}$ and inductively coupled plasma mass spectrometry (ICP-MS $)^{[9]}$. The basic principle of the approach remained the same: first, ceramic assemblages are characterised in terms of their elemental content and then they are grouped statistically on the basis of similarities in composition. Petrographic/ mineralogical and archaeological/ stylistic data should also be incorporated in the classification, as part of a more integrated approach ${ }^{[10,11]}$. Subsequently, groups or individual samples of unclear origin are compared with reference data, from pottery which can be assigned to specific production places. In some cases pottery is also compared with extant clay sources, even though clay mixing and modification of the clay paste has to be considered as well as the possible exhausting of ancient clay deposits. For this reason, replicates simulating ancient recipes deduced from appropriate understanding of the ancient technologies are preferred for this purpose $^{[11]}$. Comparisons are valid as the composition usually remains largely unchanged from clay paste over finished product to the excavated artefact: firing, for example, largely leaves the composition unaffected ${ }^{[12-14]}$, although there are changes in a range of elements that may occur during processing and burial which should be considered when evaluating data ${ }^{[15,16]}$.

For a successful provenance study based on elemental composition of archaeological ceramics there are certain requirements for the applied analytical method in terms of precision as well as in terms of the examined element suite. As elemental variability between the defined pottery compositional groups of different clay pastes is examined in relation to the chemical variability within a single group, the analytical uncertainties of the applied method must be lower than these variabilities to avoid obscuring them. In addition, the determined elements have to be geochemically significant. Trace element concentrations, such as these of lanthanides or actinides, have been identified as particularly efficient in distinguishing meaningfully between specific pottery groups, while major element concentrations are often affected by the technologically related varying content of non-plastic inclusions such as rock or mineral temper ${ }^{[17]}$. Such variations indeed interfere also with the absolute concentrations of trace elements, these being found mainly in the finer fraction of the original raw materials, but the ratios among each other remain usually unaffected, as common temper materials such as quartz or calcite are relatively poor in trace elements ${ }^{[13]}$. For ceramics with inclusions that contain multiple elements and/or considerable amounts of trace elements (e.g. rock fragments, grog temper) the situation can be more complex.

In order to understand potentially complex patterns of ceramic circulation through elemental analysis, large datasets are needed, frequently necessitating comparison of results produced by different laboratories. In this case, apart for the selected element suite, which should be ideally the same, the accuracy of the analytical data also becomes important. Interlaboratory calibration studies have proven that it is possible not only to compare data acquired using the same analytical method but also up to 
some extent to compare data collected by using different methods ${ }^{[18-21]}$. For this, a set of common samples, preferably certified reference materials (CRMs), is measured in the different laboratories and systematic deviations can be corrected for by determining calibration factors.

The analytical examination of archaeological ceramics, finally, has a further important constraint. As the analysed material belongs to an archaeological artefact, even if it is in most cases a fragment or sherd, the integrity of the artefact should be considered. If it is necessary to take a sample, which due to the demanding requirements in analytical precision and accuracy is usually the case for provenance studies, this should be as small as possible. Furthermore, for the same reason, as unique archaeological artefacts cannot be sampled multiple times, data produced from archaeological samples should be able to stand progress in analytical instrumentation and remain valuable as reference, comparative measurements.

From the above it becomes clear that the complexity of archaeological ceramic provenance research places high requirements in terms of acquiring large, relevant, and good quality datasets. Long-term validity of data ${ }^{[22]}$ and interlaboratory comparability are key and for this laboratories must ensure their methodologies are clearly outlined and the quality and limitations of the data produced are assessed and presented. Experimental reproducibility is also key to scientific research. This is precisely the scope of the current paper.

The set-up described here involves the use of a wavelength dispersive X-ray fluorescence spectrometer (WDXRF) at the Fitch Laboratory of the British School at Athens. The Fitch Laboratory has a long reputation as a centre for archaeological ceramic analysis using ceramic petrography ${ }^{[23-27]}$ as well as chemical analysis, with different techniques used over the years, including ED-XRF, $\mathrm{AAS}^{[28]}$, and ICP$\mathrm{OES}^{[11,30,31]}$. The methodology developed for ceramic analysis using this most recently acquired technique offers a full chemical profile including all major and minor elements relevant for ceramic analysis, as well as a significant suite of trace elements. Apart from the reasons outlined above the selected suite of elements aimed to enable greater comparability with a vast amount of NAA data collected in over 60 years of research in the Mediterranean region ${ }^{32,33]}$. The calibration parameters and performance characteristics of the developed procedure are described in detail below.

\section{Sample preparation}

Given the restrictions concerning sample sizes when dealing with archaeological materials, sample preparation for this method needed to balance between minimising sample requirements and maximising analytical output. Geochemical laboratories usually use diluted glass beads for major/ minor element analyses and pressed pellets for trace element analyses. In this case, as in other laboratories with dedicated routines for the analyses of archaeological ceramics ${ }^{[34,35]}$, a compromise was made to use concentrated glass beads for analysis of all major, minor, and a suite of trace elements. The method adopted following experimentation is described below.

A fragment is cut from the ceramic sherd, weighing approximately $1.5 \mathrm{~g}$. Its external surface is removed using a tungsten carbide handheld drill and after removing dust with pressurised air, the sample is pulverised on an automatic agate ball mill to a fine powder. Loss on ignition is measured by heating the powder to $950^{\circ} \mathrm{C}$ for four hours in a muffle furnace. The glass beads are prepared on an automatic fluxer by mixing $1 \mathrm{~g}$ 
of the ignited sample with $6 \mathrm{~g}$ of a lithium borate mixture $(34.83 \% \mathrm{LiT} / 64.67 \% \mathrm{LiM} /$ $0.5 \% \mathrm{LiBr}$ ) and cast in a $32 \mathrm{~mm}$ bead. In the case of samples rich in basic oxides (e.g. very calcium or magnesium-rich) a different lithium borate mixture is used $(49.75 \% \mathrm{LiT} / 49.75 \% \mathrm{LiM} / 0.5 \% \mathrm{LiBr}$ ) in the same ratio to the sample as above. Experiments were made that indicated that the use of these slightly modified fluxes did not influence the calibration and this is additionally clear on the basis of the excellent coefficients of determination noted in the calibration lines of most elements (Table 2).

\section{Set-up of analytical method}

The instrument is a BRUKER S8 TIGER with a $4 \mathrm{~kW} \mathrm{Rh} \mathrm{X}$-ray tube. The system is equipped with five analysing crystals (LiF 200, PET, XS -55, LIF-220 \& Ge), two detectors (flow and scintillation counter), seven filters $(\mathrm{Cu} 300 \mu \mathrm{m}, \mathrm{Cu} 200 \mu \mathrm{m}, \mathrm{Al} 800$ $\mu \mathrm{m}, \mathrm{Al} 500 \mu \mathrm{m}, \mathrm{Al} 200 \mu \mathrm{m}, \mathrm{Al} 100 \mu \mathrm{m}$, and Al 12,5 $\mu \mathrm{m})$, two collimators $\left(0.23^{\circ}\right.$ and $\left.0.46^{\circ}\right)$, and six beam masks (34mm, 28mm, 23mm, $18 \mathrm{~mm}, 8 \mathrm{~mm}$, and $5 \mathrm{~mm}$ ).

The analytical method is calibrated to measure 26 elements: $\mathrm{Na}, \mathrm{Mg}, \mathrm{Al}, \mathrm{Si}, \mathrm{P}, \mathrm{K}, \mathrm{Ca}$, $\mathrm{Ti}, \mathrm{Fe}$ are given as oxides in weight $\%$, and $\mathrm{V}, \mathrm{Cr}, \mathrm{Mn}, \mathrm{Co}, \mathrm{Ni}, \mathrm{Cu}, \mathrm{Zn}, \mathrm{Rb}, \mathrm{Sr}, \mathrm{Y}, \mathrm{Zr}$, $\mathrm{Ba}, \mathrm{La}, \mathrm{Ce}, \mathrm{Nd}, \mathrm{Pb}$, Th as elements in ppm. The selection covers all major and minor elements relevant to ceramics and soils, as well as a substantial suite of trace elements that will be useful, particularly for provenance purposes. In addition, as $\mathrm{LiBr}$ is included in the glass beads, $\mathrm{Br}$ is also measured but not calibrated so that it can be used in overlap corrections for some elements.

A total of 43 CRMs were used for the development of the calibration. They were selected to represent a wide spectrum of compositions aiming to develop a method that could be used for the analysis of different types of ceramics and relevant raw materials. Only a subgroup of these CRMs could be used for each element, as they did not all contain certified values for all elements analysed (Table 1). Almost all elements, with the exception of the line CaKa1-Maj, measuring calcium in high contents (see below), are characterized with a minimum of 20 CRMs. Several certified values were excluded, as they appeared as 'outliers' in the calibration. The decision to exclude a certified value from the calibration may be due to one of several reasons: a) influence on the value by another element only because it is present in abnormally high concentrations and therefore overlap correction is not justified (e.g. Ni Ka first order overlap with Co in CG07102 or Zr Ka third order overlap with Nd in SARM3); b) extremely high values for that element in the standard that were deemed outside the region of interest for the method (e.g. Na and Zr in SARM3); c) decision that the particular element was probably certified with poor accuracy (e.g. Mn in GSS7).

All elements are measured using one set of line parameters. The only exception is calcium, for which two line parameter set-ups are included to calibrate for high (CaKA1-Maj) and lower (CaKA1-Min) calcium contents, as this was deemed necessary to accommodate for the large range of values. The default line is CaKA1-Min, however, if the count rate exceeds a certain threshold then the line parameters for CaKA1-Maj are automatically used. The line parameters selected for each element are given in Table 2. Measurements are carried out using the $28 \mathrm{~mm}$ mask. Counting times for each element are controlled by a target counting statistical error, set during method development (CSE column in Table 2) up to a maximum counting time defined (Table 2, column Max Ct t). Matrix corrections were done using the Fundamental Parameter- 
based theoretical variable alphas deduced using the BRUKER software. The resulting calibration lines show excellent coefficients of determination $\left(\mathrm{R}^{2}\right)$ for most elements (Table 2) with a lower value noted only for $\mathrm{Cu}$.

\section{Performance of the analytical method}

In order to test the performance of the method ten runs of fifteen reference materials not included in the calibration and of compositions similar to ceramics and soils were tested. These are nine CRMs and six non-certified materials prepared as in-house reference materials for pottery analyses:

- NCS DC73301 (GSR-1), a rock from the China National Analysis Center for Iron and Steel (CNACIS)

- PM-S, a microgabbro (Scotland) from the International Working Group Groupe International de Travail (IWG-GIT)

- GBW 07307a (GSD-7a) and GBW 07311 (GSD-11) are stream sediments from the National Research Centre for Certified Reference Materials, China

- IPT32 is a plastic clay (Saracuna, Brazil) from Instituto de Pesquisas Technológicas, Brazil

- Kaolin KK, a kaolin from ÚNS - Laboratorní služby, s.r.o., Czech Republic

- SRM2711a the Montana II Soil and SRM679 a brick clay, both from the National Institute of Standards and Technology (NIST)

- $\quad$ SO-3 is a Guelph series soil from the Canada Centre for Mineral and Energy Technology

- Bonn Standard, ceramic material, which was developed as an in-house standard on the basis of the Berkeley Standard ${ }^{[20,36,37]}$. Values given in Table 5 for this material are based on 'Bonn Standard Values' given in Table 1 of Hein et al $(2002)^{[20]}$, with the exception of elements $\mathrm{Mg}, \mathrm{Al}, \mathrm{Mn}, \mathrm{Sr}$, and $\mathrm{Zr}$ which are taken from Table 4 of the same ${ }^{[20]}$. The former have been estimated with NAA, while the latter are the means of a set of NAA, WDXRF, ICP-OES and ICPMS.

- Podmore, ceramic material developed as an in-house standard by the Manchester Archaeometry Group ${ }^{[38,39]}$. The data used as reference values in Table 5 are the NAA Berkeley data that can be found at http://archaeometry.missouri.edu/datasets/uman/index.html under the column Perlman with the exception of $\mathrm{V}$ not measured by Berkeley, in which case the Manchester 'Radiochemistry' value is used.

- OG18, Ohio Gold Clay; developed as in-house standards by the Archaeometry Laboratory at the Missouri University Research Reactor (MURR) with reported values estimated by NAA (data provided by M. Glascock)

- NOR18, New Ohio Red Clay; as for OG18

- TF18, Talc Free Clay; as for OG18

- Pikermi clay, homogenised clay from Attica, Greece, developed as in-house standard by the Laboratory of Archaeometry NCSR Demokritos. The values reported here are the averages from repeated measurements from 11 analytical set-ups including ICP-OES, ICP-MS, WDXRF, NAA, and AAS (unpublished data, Demokritos, 2002). 
The lower limit of detection (LLD) of an analytical method is the smallest amount of the analyte, which can be detected, corresponding to the minimum net signal, which exceeds the background signal with a certain level of confidence ${ }^{[40,41]}$. It can be estimated on the basis of the statistical error $\sigma_{B}$ of the mean background signal $\bar{x}_{B}$. In the case of the LLD commonly a value of $3 \cdot \sigma_{B}$ is estimated for the minimum net signal corresponding to a confidence level of 0.05 for false background signal ${ }^{[41]}$. In order to quantify the amount of the analyte, however, the limit of determination (LOD) is estimated with $6 \cdot \sigma_{B}$ or, in the case that an acceptable experimental error should be achieved, the limit of quantification (LOQ) with $10 \cdot \sigma_{B}$, respectively.

The Bruker software estimates automatically the LLD for each measured sample as:

$$
L L D=\frac{3}{m} \sqrt{\frac{I_{B k g}}{t}}
$$

In which $m$ is the sensitivity, $I_{B k g}$ is the intensity of the background at a given wavelength, and $t$ is the background counting time ${ }^{[42]}$. The LLD for each element is dependent on the matrix and on the presence of overlaps on the background wavelength. Smaller or larger deviations depending on the matrix are thus to be expected. Table 3 summarises the LLD calculated from the materials analysed in this study. Although these are all ceramic or soil-related materials, there are variations in the represented matrices reflected in the range of calculated LLDs. LOD and LOQ are calculated on the basis of the LLD averages.

While the method used here does account for the calibration coefficient and matrix corrections, it does not account for the presence of offsets in the calibration lines. An example where this is evident is $\mathrm{Rb}$. $\mathrm{RbK} \alpha$ line largely overlaps the $\operatorname{BrK} \beta$ line. Although an overlap correction for $\mathrm{BrK} \beta$ is applied to $\mathrm{RbK} \alpha$, an offset is still necessary to ensure better fit, showing that the calibration cannot compensate at very low concentrations of $\mathrm{Rb}$ given the abundance of $\mathrm{Br}$ in all samples due to the $\mathrm{LiBr}$ in the flux used. A corrected intensity offset of $-18 \mathrm{ppm}$ was applied on the calibration curve for $\mathrm{Rb}$. The method therefore suffers from a systematic error, providing a false zero value, with $18 \mathrm{ppm}$ being the minimum $\mathrm{Rb}$ content reported (see accuracy section below). However, the method is optimized to the element range expected more commonly for ceramics $70-160 \mathrm{ppm}^{[17]}$. Similar offsets were applied to $\mathrm{Sr}(-15 \mathrm{ppm}), \mathrm{Zr}$ $(-9 \mathrm{ppm})$, and $\mathrm{Ba}(-10 \mathrm{ppm})$, but again although the LLDs will thus be affected, elements are optimized for the concentration regions of interest.

\section{Precision}

The precision can be estimated with the coefficient of variation $(\mathrm{CV})$ which is the relative standard deviation as percent of the mean value ${ }^{[43]}$. Table 4 summarises control measurements presenting mean values and CVs for each reference material, based on ten measurements in each case. An average relative standard deviation is provided in the last column, not considering CVs of element concentrations below the LOQ. Based on these control measurements, the estimated precision is definitely satisfactory for major and minor elements, with CVs in general less than $1 \%$, and in 
many cases below $0.5 \%$. In the case of trace elements, $\mathrm{CVs}$ generally do not exceed $5 \%$, with the exception of $\mathrm{La}, \mathrm{Ce}, \mathrm{Nd}$, and $\mathrm{Th}$, for which the CVs do not exceed $10 \%$. As the reference materials were selected according to typical compositional ranges in archaeological pottery, the precision can be considered as sufficient for the method to be used for chemical provenance studies. As expected CVs increase significantly as contents approach the limits of quantification for each element. In the case of Co for example, the higher average $\mathrm{CV}$ noted is due to the incorporation of several standards with Co values approaching the LOQ (10 ppm).

\section{Repeatability}

The repeatability of the method depends on the long-term precision as well as on the sample preparation. This instrument suffers from two main sources of long-term drift, tube ageing, which will affect the intensity of all measured lines, and ageing of the PET crystal, which will affect the intensities of the $\mathrm{Al}$ and Si lines. The instrument is continuously monitored for drift and accordingly corrected periodically using standards provided by the manufacturer. Similarly, in order to assess long-term variation in the ceramic calibration two CRMs are included daily with every run of samples. Presently there is not adequate data to assess statistically long-term variation, but systematic monitoring will ensure that the method is periodically drift-corrected as necessary by re-calibration.

Sample preparation is an important parameter in repeatability assessment. Glass beads offer a flat, homogeneous surface ideal for XRF analysis, while the dilution minimises matrix effects allowing for larger compositional variations to be considered using the same calibration. As large numbers of samples are prepared for these analyses, often by different staff members, an experiment was made to assess repeatability in the sample preparation procedure described above. Two different staff members prepared five glass beads of the Pikermi clay. All glass pellets were measured on the same day. Another glass bead made from the Pikermi clay was analysed ten times with the remaining group of standards, approximately ten days earlier (Table 4). Figure 1 summarises the collected data in boxplots depicting the results per element normalised to the mean values of the repeated measurements of the single bead (Table 4). The repeated measurements on the same bead (Table 4) are compared with the measurements of the ten different beads in order to compare the repeatability of sample preparation to the precision of the method. The most significant increases in the total spread of data for the major elements are seen for $\mathrm{Al}, \mathrm{Si}$, and $\mathrm{Ca}$, where increase in the corresponding CVs is threefold or higher. Still, for these elements this increase will not have a significant effect, as the overall repeatability is still excellent with corresponding CVs within $1 \%$. Amongst the traces threefold or higher increase in $\mathrm{CV}$ s was noted for $\mathrm{Cr}, \mathrm{Ni}, \mathrm{Cu}, \mathrm{Rb}$, and $\mathrm{Zr}$. In the case of $\mathrm{Ni}$ and $\mathrm{Cr}$ the variation is to a large extent due to one sample, B5, which showed significantly increased concentrations in these two elements and appears as an outlier in Figure 1 for both elements. This deviation is clearly due to sample heterogeneity and incorporation of a clay fraction significantly richer in these elements, instead of a problem with sample preparation as such. Unfortunately, this type of natural variation is not uncommon in clays and coarse ceramics and is not specific to this method, highlighting that analysts need to be aware of potential effects in group assignment ${ }^{[11]}$. For the remaining elements despite the increase in variation for $\mathrm{Rb}$ and $\mathrm{Zr}$, when multiple beads were prepared, CVs were still within 5\%. Th showed the largest spread of values, almost 
double that of the repeated measurements on one bead. Overall, this test does illustrate the added limitations introduced by sample preparation to repeatability, but CVs did not generally significantly deteriorate and they remained within the levels noted under the precision section, with only $\mathrm{Th}$ and $\mathrm{Cu}$ exceeding $10 \%$.

\section{Accuracy}

In order to test the accuracy of the calibration set up the measured values are compared with the certified or reference values of the standards used. It should be noted again that only nine of these materials are actually certified. These were selected deliberately to represent materials of different compositions in order to test the performance of the method across different ceramic matrices. Such variability in composition is common within archaeological ceramics and the method developed needs to be tested across the range. The remaining materials are in-house standards and reported values should only be considered as indicative ${ }^{[44]}$.

Both mean and median values for individual elemental concentrations are reported in Table 5, assisting in the identification of potential analytical outliers ${ }^{[20]}$. The table also gives upper and lower deciles, excluding the lowest and highest $10 \%$ of the measurement values. The last column for each standard presents the averages of the mean to the certified or reference value, immediately highlighting any significant deviations between the two.

Looking first individually at the nine CRMs, nearly all elements are in very close agreement with the certified values, showing agreement usually within $+/-3 \%$ for most of the major, minor, and trace elements with a few reaching to $+/-10 \%$. A few elements for each standard show errors higher than $+/-10 \%$ and these are highlighted in bold in the ratio column, except for those where values given were only reference and not certified (in Italics in the certified column). It is immediately clear that many of these are below or close to the limit of detection and hence deviations should be expected. Exceptions are $\mathrm{Na}$ and $\mathrm{Mg}$ for Kaolin $\mathrm{KK}$, and for Na only IPT32 and SRM679; P for IPT32 and Kaolin KK; Ca for IPT32; Cr and Ni for SRM2711a; Cu for GBW07307, Kaolin KK, and SO3; Zn and Y for NCS DC73301 (GSR-1); Rb for GBW07307, GBW07311, and PM-S; Th for GBW07311; and Pb for GBW07311, Kaolin KK, and SRM2711a.

The slightly overestimated $\mathrm{Na}$ and $\mathrm{Mg}$ values for Kaolin $\mathrm{KK}$ may be due to the very high alumina of this clay and the low values of these elements. Overall the accuracy of $\mathrm{Na}$ is consistently poorer, where its oxide is below c. $0.4 \%$.

$\mathrm{Cr}$ and $\mathrm{Ni}$ on the other hand are well within the $10 \%$ range for all measured CRMs, where the values are well above detection limits, with the exception of SRM2711a, in which both elements are significantly overestimated with the measured contents more than double the certified values. A potential reason could be a singular enrichment through chromium/nickel bearing components, which were heterogeneously distributed in the powdered CRM.

$\mathrm{Cu}$ was measured quite poorly with three CRMs (GBW07307; Kaolin KK; SO3), but well within acceptable ranges for the rest. It is unclear what the cause of the deviations are for the problematic samples; it may be the certified values themselves or effects of 
sample preparation. In this context it should be noted that $\mathrm{Br}$ from the non-wetting agent used in the manufacture of the beads forms volatile compounds with $\mathrm{Cu}$, which may be lost during fusion and cause erroneous results ${ }^{[45]}$. Still, in this method copper is measured primarily as an indicator for contamination, where there is an association with metallurgy or copper-based pigments, and is generally not included in the statistical treatment of the data for grouping of the ceramics. Similarly lead, which was also problematic for some samples, is only measured as an indicator of contamination and for the application of relevant corrections, where lead glazed samples are analysed. Therefore, good accuracy of the measured values is less of a concern for these two elements.

A noteworthy deviation is also that of $\mathrm{Rb}$ in PM-S. Although the element has a certified value of $1 \mathrm{ppm}$, the instrument consistently reported $18 \mathrm{ppm}$ in all repeats. As explained above in the LLD section, this is due to an applied corrected intensity offset that leads to a systematic error in $\mathrm{Rb}$ concentrations below $18 \mathrm{ppm}$. It is less clear why there are deviations for some of the other CRMs measured (e.g. GBW07307a and GBW07311), especially as the element is measured well within accepted limits for the rest and for the range of non-certified materials tested. The deviating values must probably be attributed to problems with the specific standards.

With regards to the other reference materials analysed here, as their values are not certified, it is unclear whether the deviations noted from the reference value are due to problems with the accuracy of this specific calibration method or the reported certified values, or alternatively heterogeneity within the materials. For the three MURR samples, the values given have resulted from Neutron Activation Analyses (NAA) at MURR only. In the case of $\mathrm{Zr}$, the element shows consistent, systematic errors between the two set-ups, with the ratio between measured and 'reference' value averaging at 1.3 with a standard deviation of 0.2. Systematic deviations in the MURR Zr measurements have been noted before and these probably explain this picture ${ }^{[46]}$. Sodium is also systematically overestimated with the Fitch Laboratory WD-XRF compared to the MURR NAA, primarily for the lowest contents, while $\mathrm{Zn}$ is systematically underestimated. Significant deviations are noted in the Ni contents between the two laboratories, but the errors are not systematic.

The Bonn Standard was amongst the materials tested in an inter laboratory calibration study, comparing set-ups for the analysis of archaeological ceramics using Neutron Activation Analysis, Wavelength Dispersive X-Ray Fluorescence, Inductively Coupled Plasma Optical Emission Spectrometry, and Inductively Coupled Plasma Mass Spectrometry ${ }^{[20]}$. Comparison between these methods showed significant deviations for some elements, specifically $\mathrm{Cr}, \mathrm{Ni}$, and $\mathrm{Zr}$, and the reference values for these are given in italics in Table 5. The majority of the reference values considered here are those of the Bonn NAA set-up with the exception of $\mathrm{Mg}, \mathrm{Al}, \mathrm{Mn}, \mathrm{Sr}$, and $\mathrm{Zr}$, which are the means of the set-ups used in Hein et al. 2002 ${ }^{[20]}$. Agreement between the reference values of $\mathrm{Cr}, \mathrm{Ni}$, and $\mathrm{Zr}$ and the current set-up are in most cases poor, which is most likely due to the reported problems of the reference values ${ }^{[20]}$. Other than these, the measurement for $\mathrm{Cu}$ is also much lower than the value reported by NAA. Unfortunately $\mathrm{Cu}$ was not amongst the elements tested in the inter laboratory study, so it is unclear to what extent this reflects problems of accuracy with this WD-XRF set-up. $\mathrm{Zn}$ is underestimated on the Bonn standard measurement, similarly to the MURR standards. This discrepancy reflects a systematic error in the $\mathrm{Zn}$ measurements with the two 
methods (although the MURR and Bonn standards are measured by different NAA laboratories) and would need to be corrected if NAA and WDXRF data are to be compared. The deviations in zinc contents in the Bonn standard amongst different analytical units and methods were also evident in Hein et al. 2002 ${ }^{[20]}$.

From the above there seems to be a systematic deviation between the current WDXRF set-up and the NAA data for the standards Bonn, OG18, NOR18, TF18, and Podmore for the elements $\mathrm{Zn}$, which is systematically underestimated by the latter, and $\mathrm{Zr}$, which is overestimated. Comparability of the current set-up with the above-mentioned set-ups is crucial as a large body of data for Aegean/ Mediterranean ceramics has been generated over the last decades by the relevant NAA laboratories. The issue of interlaboratory and inter-method comparability, however will be further investigated through a dedicated study using both standards and real archaeological samples ${ }^{[21]}$.

The CRMs tested represent a range of compositions from kaolinitic clays with very high alumina contents to highly calcareous ceramics (SO3) or ceramics with high lead (SRM2711a) or very low rare earth element (PM-S) contents. XRF analysis is susceptible to matrix effects and often limited by peak overlaps and other complications. Some of these problems are apparent in some of the materials analysed here, as was highlighted in the above discussion. However, it is also evident that the accuracy estimates for this set-up are very good for the elements analysed across a range of compositions common within archaeological ceramics.

\section{Discussion}

Provenance of archaeological materials, ceramics in particular here, is a complex research field that strives, far beyond establishing compositional groupings, to unravel intricate human behaviour reflected in diverse technological choices, as well as to balance varied environmental parameters both in the nature of raw materials, as well as post-depositional alterations ${ }^{[47]}$. These complications concern subsequent interpretation of chemical data to reach meaningful, substantiated conclusions about ancient pottery production and circulation patterns. The first problem, however, remains the generation of sound chemical data, sufficiently accompanied by information on analytical methodology and performance to ensure long-term validity and comparability. As with any other scientific field, publication of the actual data is of paramount importance for the wider scientific community to be able to assess the validity of the conclusions reached. This is even more so in this case, where the development of provenance studies relies on the existence of extensive comparable datasets to adequately characterise the composition of different production workshops across wide geographical and chronological horizons. The creation of openly available databases of raw analytical data ${ }^{[32]}$ forms a significant step forward to this effect. Their applicability and long-term relevance again, however, rely on adequate information on analytical performance.

The present paper outlined the analytical parameters of this dedicated WDXRF calibration, promoting the reproducibility of the method, and reported on its performance along a range of compositions. Most elements are measured with adequate accuracy and precision to be incorporated in statistical evaluations and group formation in archaeological ceramic studies. Problems were noted with some 
elements, $\mathrm{Pb}$ and $\mathrm{Cu}$ primarily, but these would not normally be considered for grouping. Furthermore, the current analytical set-up offers several advantages important in chemical analyses of ancient ceramics. First, it analyses for a wide range of elements, covering all major and minor components and a sufficient number of trace elements. Glass beads provide a homogeneous, flat and perfectly repeatable sample with the added advantage that they can be stored long-term under appropriate conditions, allowing for re-runs should those be required. Particularly in the case of CRMs this allows for long-term repeatability studies. The larger sample sizes required for this method, c. $1.5 \mathrm{~g}$ starting material, compared to $100 \mathrm{mg}$ usually for NAA or ICP-MS, might be considered a limitation in cultural heritage materials analyses. For ceramic analyses sampling tends to be less of a problem, due to the abundance and usually fragmentary state of archaeological finds. More importantly, despite the smaller sample sizes permitted by other methods, in particular for coarse ceramics, the removal and homogenisation of larger samples is always recommended in order to increase sample representativeness.

In this context a comment can be made about the use of non-invasive approaches in ceramic analyses, as methods such as EDXRF (often portable) find increasing use in this field ${ }^{[48-51]}$. When used 'non-destructively', XRF analysis is applied directly to the surface of an ancient ceramic, without any sample removal or preparation. The advantages of this approach for cultural heritage objects is evident and their attractiveness is not surprising. Naturally in order to characterise the bulk of the ceramic fabric, the surface must be clean of any post-depositional encrustations or applied painted decoration or glazing. Appropriate calibrations can be prepared and tested using CRMs, but the approach will inherently lack repeatability, as the sample presentation cannot be standardised. Mineralogical effects, heterogeneity, surface texture and geometry will vary between samples. Testing the method using appropriately prepared CRMs does not account for this step in the process. The approach is not, however, without its potential. Non-invasive analysis of ceramics can be used for classification and grouping within assemblages, particularly if groups can be formed on the basis of discriminating elements measured well with XRF. But comparability of data with other set-ups and incorporation into larger databases for larger scale studies will be limited by the lack of repeatability.

The vast majority of methods used for elemental characterisation of ceramics are invasive and require the removal of a sample. Sampling cultural heritage objects creates an ethical obligation to generate robust data that will have long-term validity. Particularly where this data is to be used to address broader archaeological questions concerning materials circulation and provenance, comparability and inter-laboratory validation are also a requirement. The tests outlined in this paper have provided information on the method's performance that will ensure that the data generated from archaeological objects with this method fulfil these conditions.

\section{Acknowledgments}

We are grateful to V. Thirion-Merle and Y. Waksman for advice on sample preparation and instrument set-up, as well as to U. Schneider for training and addressing a number of questions during calibration. V. Kilikoglou and M. Glascock kindly provided reference materials for analyses and the relevant data. 


\section{References}

[1] P. C. Weigand, G. Harbottle, E. V. Sayre, in Exchange Systems in Prehistory, Studies in Archaeology, (Eds. T. K. Earle and J. E. Ericson), Academic Press, New York, 1977, pp. 15-34.

[2] E. V. Sayre, R. W. Dodson, AJA 1957; 61, 35-41.

[3] W. J. Young, F. E. Whitmore, Far Eastern Ceramic Bulletin 1957; 9, 1-27.

[4] E. E. Richards, K. F. Hartley, Nature 1960; 185, 194-196.

[5] H. W. Catling, A. E. Blin-Stoyle, E. E. Richards, E.E., Archaeometry 1961; 4, 31 38.

[6] M. J. Hughes, M. R. Cowell, P. T. Craddock, Archaeometry 1976; 18, 19-37.

[7] H. Hatcher, R. E. M. Hedges, A. M. Pollard, P. M. Kenrick, Archaeometry 1980; $22,133-151$.

[8] F. A. Hart, S. J. Adams, Archaeometry 1983; 25, 179-185.

[9] L. M. Mallory-Greenough, J. D. Greenough, J.V. Owen, J. Archaeol. Sci. 1998; 25, 85-97.

[10] P. M. Day, E. Kiriatzi, A. Tsolakidou, V. Kilikoglou, JAS 1999; 26, 1025-36.

[11] E. Kiriatzi, M. Georgakopoulou, A. Pentedeka, in Pottery Production and Supply at Bronze Age Kolonna, Aegina: an Integrated Archaeological and Scientific Study of a Ceramic Landscape, (Eds: W. Gauss and E. Kiriatzi), Austrian Academy of Science, Vienna, 2011, pp. 69-156

[12] J. W. Cogswell, H. Neff, M. D. Glascock, J. Archaeol. Sci. 1996; 23, 283-287.

[13] V. Kilikoglou, Y. Maniatis, A. P. Grimanis, Archaeometry 1988; 30, 37-46.

[14] A. Schwedt, H. Mommsen, Archaeometry 2007; 49, 495-509.

[15] J. Buxeda i Garrigòs, J. Archaeol. Sci. 1999; 26, 295-313.

[16] A. Schwedt, H. Mommsen, N. Zacharias, J. Buxeda i Garrigòs, Archaeometry 2006; 48, 237-251.

[17] A. Hein, J. Maran, H. Mommsen, J. Archaeol. Sci. 1999; 26, 1053-58.

[18] G. Harbottle, in Archaeological Ceramics, (Eds: J.S. Olin, A.D. Franklin)

Smithonian Institution Press, Washington, D.C., 1982, pp. 67-77.

[19] H. Hatcher, M. S. Tite, J. N. Walsh, Archaeometry 1995, 37, 83-94. 
[20] A. Hein, A. Tsolakidou, I. Iliopoulos, H. Mommsen, J. Buxeda I Garrigós, G. Montana, V. Kilikoglou, Analyst 2002; 127, 542-553.

[21] N. S. Müller, A. Hein, M. Georgakopoulou, V. Kilikoglou, and E. Kiriatzi, JAS: Reports in press.

[22] M. Pollard, C. Batt, B. Stern, and M. M. Young, Analytical Chemistry in Archaeology, Cambridge University Press, Cambridge, 2007.

[23] J. Hilditch, E, Kiriatzi, K. Psaraki, V. Aravantinos, in Proceedings of the 4th Symposium of the Hellenic Society for Archaeometry, National Hellenic Research Foundation, Athens 28-31 May 2003 (Eds: Y. Facorellis, N. Zacharias, K. Polikreti), Archaeopress, Oxford, 2008, pp. 263-268.

[24] L. Joyner, Hesperia 2007; 76, 183-227.

[25] E. Kiriatzi, in METRON: Measuring the Aegean Bronze Age. Proceedings of the $9^{\text {th }}$ International Aegean Conference, New Haven, Yale University, 18-21 April 2002 (Eds: K.P. Foster and R. Laffineur), Université de Liège, Liège, 2003, pp. 123-30.

[26] I. K. Whitbread, Greek Transport Amphorae: A Petrological and Archaeological Study, Fitch Laboratory Occasional Paper 4, British School at Athens, London, 1995.

[27] I.K. Whitbread, E. Kiriatzi, T. Tartaron, in Modern Trends in Scientific Analysis on Ancient Ceramics (Eds: V. Kilikoglou, A. Hein, kal Y. Maniatis), Archaeopress, Oxford, 2002, pp. 121-128.

[28] R. E. Jones, Greek and Cypriot Pottery, A Review of Scientific Studies (Fitch Laboratory Occasional Paper 1), British School at Athens, Athens, 1986.

[30] P. A. Mountjoy, M. J. Ponting, BSA 2000; 95, 141-184.

[31] I.K. Whitbread, M. J. Ponting and B. Wells, Journal of Field Archaeology 2007; $32,177-193$.

[32] A. Hein, V. Kilikoglou, Archaeometry 2012, 54, 230-243.

[33] V. Kilikoglou, A. P. Grimanis, A. Tsolakidou, A. Hein, D. Malamidou, Z. Tsirtsoni, Archaeometry 2007; 49, 301-319.

[34] M. Mackensen and G. Schneider, J. Rom. Arch. 2002; 15, 121-159.

[35] S. Y. Waksman, Levant 2011; 43, 201-212.

[36] I. Perlman, F. Asaro, Archaeometry 1969; 11, 21-52. 
[37] H. Mommsen, B. L. Sjöberg, Archaeometry 2007; 49, 359-371.

[38] W. Krywonos, G. W. A. Newton, V. J. Robinson, J. A. Rileyb, J. Archaeol. Sci., 1982; $9,63-78$.

[39] J. E. Tomlinson, in Modern trends in Scientific Studies on Ancient Ceramics, (Eds. V. Kilikoglou, A. Hein and Y. Maniatis), BAR International Series, Oxford, 2002, pp. 35-43.

[40] L. A. Currie, Pure Appl. Chem. 1995; 67, 1699-1723.

[41] A. N. Kadachi, A. Al-Eshaikh, X-Ray Spectrometry 2012; 41, 350-354.

[42] Spectra ${ }^{\text {plus }}$ V.2 for S8 TIGER Reference Manual, 2008, Bruker AXS GmbH, Karlsruhe.

[43] P. J. Potts, A Handbook of Silicate Rock Analysis, Springer Science and Business Media, New York, 1992.

[44] J. S. Kane, Geostandards Newsletter 2001; 25, 7-22.

[45] J. Willis, C. Feather, K. Turner, Guidelines for XRF analysis, J. Willis consultants, Cape Town, 2014.

[46] M. D. Glascock, M. P. Anderson, J. Radioanal. Nucl. Chem. 1993; 174, 229-242.

[47] L. Wilson, A. M. Pollard, in Handbook of Archaeological Sciences, (Eds. D. R. Brothwell, A. M. Pollard), John Wiley and Sons, Chichester, 2001, pp. 507-517.

[48] D. Frankel, J. M. Webb, JAS 2012; 39, 1380-1387.

[49] A. Hein, in: Application of portable energy-dispersive X-ray fluorescence to the analysis of archaeological ceramics and glass, (Eds: G. Schneider, M. Dazkiewicz and M. Hegewisch), Topoi - Berlin Studies of the Ancient World, in press.

[50] D. Mitchell, P. Grave, M. Maccheroni, E. Gelman, JAS 2012; 39, 2921-2933

[51] R. J. Speakman, N. C. Little, D. Creel, M. R. Miller, J. G. Iñañez, JAS 2011; 38, 3483-3496 



\begin{tabular}{|c|c|c|c|c|c|c|c|c|c|c|c|c|c|c|c|c|c|c|c|c|c|c|c|c|c|c|c|c|c|}
\hline Standard & Company & Description & $z_{w}$ & $\frac{3}{19}$ & $\geq$ & $\cong$ & 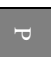 & $\pi$ & $\propto$ & ह & $\exists$ & $<$ & ? & z & $\frac{\pi}{6}$ & 8 & $\underline{z}$ & $£$ & 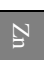 & $\pi$ & n & $\prec$ & 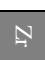 & $\underset{\infty}{\infty}$ & 5 & 8 & $\underline{z}$ & $\widetilde{\sigma}$ & $\exists$ \\
\hline AGV-2 & USGS & Andesite & $\mathrm{x}$ & $\mathrm{x}$ & $\mathrm{x}$ & $\mathrm{x}$ & $\mathrm{x}$ & $\mathrm{x}$ & $\mathrm{x}$ & & $\mathrm{x}$ & $\mathrm{x}$ & $\mathrm{x}$ & $\mathrm{x}$ & $\mathrm{x}$ & $\mathrm{x}$ & $\mathrm{x}$ & $\mathrm{x}$ & $\mathrm{x}$ & $\mathrm{x}$ & $\mathrm{x}$ & $\mathrm{x}$ & $\mathrm{x}$ & $\mathrm{x}$ & $\mathrm{x}$ & $\mathrm{x}$ & $\mathrm{x}$ & $\mathrm{x}$ & $\mathrm{x}$ \\
\hline BCR-2 & USGS & Basalt & $\mathrm{x}$ & $\mathrm{x}$ & $\mathrm{x}$ & $\mathrm{x}$ & $\mathrm{x}$ & $\mathrm{x}$ & $\mathrm{x}$ & & $\mathrm{x}$ & $\mathrm{x}$ & $\mathrm{x}$ & $\mathrm{x}$ & $\mathrm{x}$ & $\mathrm{x}$ & & & $\mathrm{x}$ & $\mathrm{x}$ & $\mathrm{x}$ & $\mathrm{x}$ & $\mathrm{x}$ & $\mathrm{x}$ & $\mathrm{x}$ & $\mathrm{x}$ & $\mathrm{x}$ & & $\mathrm{x}$ \\
\hline BE-N & GIT/IWT & Basalt & $\mathrm{x}$ & $\mathrm{x}$ & $\mathrm{x}$ & $\mathrm{x}$ & $\mathrm{x}$ & $\mathrm{x}$ & & $\mathrm{x}$ & $\mathrm{x}$ & $\mathrm{x}$ & $\mathrm{x}$ & $\mathrm{x}$ & $\mathrm{x}$ & $\mathrm{x}$ & $\mathrm{x}$ & $\mathrm{x}$ & $\mathrm{x}$ & $\mathrm{x}$ & $\mathrm{x}$ & $\mathrm{x}$ & $\mathrm{x}$ & $\mathrm{x}$ & $\mathrm{x}$ & $\mathrm{x}$ & $\mathrm{x}$ & $\mathrm{x}$ & $\mathrm{x}$ \\
\hline BHVO-2 & USGS & Basalt & $\mathrm{x}$ & $\mathrm{x}$ & $\mathrm{x}$ & $\mathrm{x}$ & $\mathrm{x}$ & $\mathrm{x}$ & & $\mathrm{x}$ & $\mathrm{x}$ & $\mathrm{x}$ & $\mathrm{x}$ & $\mathrm{x}$ & $\mathrm{x}$ & $\mathrm{x}$ & $\mathrm{x}$ & $\mathrm{x}$ & $\mathrm{x}$ & $\mathrm{x}$ & $\mathrm{x}$ & $\mathrm{x}$ & $\mathrm{x}$ & $\mathrm{x}$ & $\mathrm{x}$ & $\mathrm{x}$ & $\mathrm{x}$ & & \\
\hline BIR-1 & USGS & Icelandic basalt & $\mathrm{x}$ & $\mathrm{x}$ & $\mathrm{x}$ & $\mathrm{x}$ & $\mathrm{x}$ & $\mathrm{x}$ & & $\mathrm{x}$ & $\mathrm{x}$ & $\mathrm{x}$ & $\mathrm{x}$ & $\mathrm{x}$ & $\mathrm{x}$ & $\mathrm{x}$ & $\mathrm{x}$ & $\mathrm{x}$ & $\mathrm{x}$ & & $\mathrm{x}$ & $\mathrm{x}$ & $\mathrm{x}$ & & $\mathrm{x}$ & $\mathrm{x}$ & $\mathrm{x}$ & & \\
\hline CG07102 & NCSM China & Ultrabasic rock & $\mathrm{x}$ & $\mathrm{x}$ & $\mathrm{x}$ & $\mathrm{x}$ & $\mathrm{x}$ & $\mathrm{x}$ & $\mathrm{x}$ & & $\mathrm{x}$ & $\mathrm{x}$ & $\mathrm{x}$ & $\mathrm{x}$ & & $\mathrm{x}$ & $\mathrm{x}$ & $\mathrm{x}$ & $\mathrm{x}$ & & $\mathrm{x}$ & & & $\mathrm{x}$ & $\mathrm{x}$ & $\mathrm{x}$ & $\mathrm{x}$ & $\mathrm{x}$ & \\
\hline CG07114 & NCSM China & Dolomite & & & $\mathrm{x}$ & $\mathrm{x}$ & $\mathrm{x}$ & $\mathrm{x}$ & & & $\mathrm{x}$ & $\mathrm{x}$ & $\mathrm{x}$ & $\mathrm{x}$ & $\mathrm{x}$ & $\mathrm{x}$ & $\mathrm{x}$ & $\mathrm{x}$ & $\mathrm{x}$ & & $\mathrm{x}$ & & $\mathrm{x}$ & $\mathrm{x}$ & $\mathrm{x}$ & $\mathrm{x}$ & $\mathrm{x}$ & & $\mathrm{x}$ \\
\hline DNC-1 & USGS & Dolerite & $\mathrm{x}$ & $\mathrm{x}$ & $\mathrm{x}$ & $\mathrm{x}$ & $\mathrm{x}$ & $\mathrm{x}$ & & $\mathrm{x}$ & $\mathrm{x}$ & $\mathrm{x}$ & $\mathrm{x}$ & $\mathrm{x}$ & $\mathrm{x}$ & $\mathrm{x}$ & $\mathrm{x}$ & $\mathrm{x}$ & $\mathrm{x}$ & & $\mathrm{x}$ & $\mathrm{x}$ & $\mathrm{x}$ & $\mathrm{x}$ & $\mathrm{x}$ & & $\mathrm{x}$ & & \\
\hline DR-N & ANRT & Diorite & $\mathrm{x}$ & $\mathrm{x}$ & $\mathrm{x}$ & $\mathrm{x}$ & $\mathrm{x}$ & $\mathrm{x}$ & $\mathrm{x}$ & & $\mathrm{x}$ & $\mathrm{x}$ & & $\mathrm{x}$ & $\mathrm{x}$ & $\mathrm{x}$ & $\mathrm{x}$ & $\mathrm{x}$ & $\mathrm{x}$ & $\mathrm{x}$ & $\mathrm{x}$ & $\mathrm{x}$ & $\mathrm{x}$ & $\mathrm{x}$ & $\mathrm{x}$ & $\mathrm{x}$ & $\mathrm{x}$ & $\mathrm{x}$ & $\mathrm{x}$ \\
\hline ECRM776-1 & $\mathrm{BCS}$ & Firebrick & $\mathrm{x}$ & $\mathrm{x}$ & $\mathrm{x}$ & $\mathrm{x}$ & $\mathrm{x}$ & $\mathrm{x}$ & $\mathrm{x}$ & & $\mathrm{x}$ & & $\mathrm{x}$ & & $\mathrm{x}$ & & & & & & & & & $\mathrm{x}$ & & & & & \\
\hline FK-N & ANRT & Potash feldspar & $\mathrm{x}$ & & $\mathrm{x}$ & $\mathrm{x}$ & $\mathrm{x}$ & $\mathrm{x}$ & $\mathrm{x}$ & & $\mathrm{x}$ & $\mathrm{x}$ & $\mathrm{x}$ & $\mathrm{x}$ & $\mathrm{x}$ & $\mathrm{x}$ & $\mathrm{x}$ & $\mathrm{x}$ & $\mathrm{x}$ & $\mathrm{x}$ & $\mathrm{x}$ & $\mathrm{x}$ & $\mathrm{x}$ & $\mathrm{x}$ & $\mathrm{x}$ & $\mathrm{x}$ & $\mathrm{x}$ & & \\
\hline GA & CRPG & Granite & $\mathrm{x}$ & $\mathrm{x}$ & $\mathrm{x}$ & $\mathrm{x}$ & $\mathrm{x}$ & $\mathrm{x}$ & $\mathrm{x}$ & & $\mathrm{x}$ & $\mathrm{x}$ & $\mathrm{x}$ & $\mathrm{x}$ & $\mathrm{x}$ & $\mathrm{x}$ & $\mathrm{x}$ & $\mathrm{x}$ & $\mathrm{x}$ & $\mathrm{x}$ & $\mathrm{x}$ & $\mathrm{x}$ & $\mathrm{x}$ & $\mathrm{x}$ & $\mathrm{x}$ & $\mathrm{x}$ & $\mathrm{x}$ & $\mathrm{x}$ & $\mathrm{x}$ \\
\hline GBW07712/ & IGGE & Synthetic Limestone & & & & & & & & & $\mathrm{x}$ & $\mathrm{x}$ & $\mathrm{x}$ & $\mathrm{x}$ & & $\mathrm{x}$ & $\mathrm{x}$ & $\mathrm{x}$ & $\mathrm{x}$ & & $\mathrm{x}$ & $\mathrm{x}$ & $\mathrm{x}$ & $\mathrm{x}$ & & $\mathrm{x}$ & & $\mathrm{x}$ & \\
\hline GBW07713/ & IGGE & Synthetic Limestone & & & & & & & & & $\mathrm{x}$ & $\mathrm{x}$ & $\mathrm{x}$ & $\mathrm{x}$ & & $\mathrm{x}$ & $\mathrm{x}$ & $\mathrm{x}$ & $\mathrm{x}$ & & $\mathrm{x}$ & $\mathrm{x}$ & $\mathrm{x}$ & $\mathrm{x}$ & & $\mathrm{x}$ & & $\mathrm{x}$ & \\
\hline GBW07714/ & IGGE & Synthetic Limestone & & & & & & & & & $\mathrm{x}$ & $\mathrm{x}$ & $\mathrm{x}$ & $\mathrm{x}$ & & $\mathrm{x}$ & $\mathrm{x}$ & $\mathrm{x}$ & $\mathrm{x}$ & & $\mathrm{x}$ & $\mathrm{x}$ & $\mathrm{x}$ & $\mathrm{x}$ & & $\mathrm{x}$ & & $\mathrm{x}$ & \\
\hline GBW07715/ & IGGE & Synthetic Limestone & & & & & & & & & $\mathrm{x}$ & $\mathrm{x}$ & $\mathrm{x}$ & $\mathrm{x}$ & & $\mathrm{x}$ & $\mathrm{x}$ & $\mathrm{x}$ & $\mathrm{x}$ & & $\mathrm{x}$ & $\mathrm{x}$ & $\mathrm{x}$ & $\mathrm{x}$ & & $\mathrm{x}$ & & $\mathrm{x}$ & \\
\hline GBW07716/ & IGGE & Synthetic Limestone & & & & & & & & & $\mathrm{x}$ & $\mathrm{x}$ & $\mathrm{x}$ & $\mathrm{x}$ & & $\mathrm{x}$ & $\mathrm{x}$ & $\mathrm{x}$ & $\mathrm{x}$ & & $\mathrm{x}$ & $\mathrm{x}$ & $\mathrm{x}$ & $\mathrm{x}$ & & $\mathrm{x}$ & & $\mathrm{x}$ & \\
\hline GBW07717/ & IGGE & Synthetic Limestone & & & & & & & & & $\mathrm{x}$ & $\mathrm{x}$ & $\mathrm{x}$ & $\mathrm{x}$ & & $\mathrm{x}$ & $\mathrm{x}$ & & $\mathrm{x}$ & & $\mathrm{x}$ & $\mathrm{x}$ & $\mathrm{x}$ & $\mathrm{x}$ & & $\mathrm{x}$ & & $\mathrm{x}$ & \\
\hline GBW07718/ & IGGE & Synthetic Limestone & & & & & & & & & $\mathrm{x}$ & $\mathrm{x}$ & $\mathrm{x}$ & $\mathrm{x}$ & & $\mathrm{x}$ & $\mathrm{x}$ & & & & $\mathrm{x}$ & $\mathrm{x}$ & $\mathrm{x}$ & $\mathrm{x}$ & & $\mathrm{x}$ & & & \\
\hline GBW07719/ & IGGE & Synthetic Limestone & & & & & & & & & $\mathrm{x}$ & $\mathrm{x}$ & & $\mathrm{x}$ & & & $\mathrm{x}$ & $\mathrm{x}$ & & & $\mathrm{x}$ & & $\mathrm{x}$ & $\mathrm{x}$ & & $\mathrm{x}$ & & & \\
\hline GBW07720/ & IGGE & Synthetic Limestone & & & & & & & & & & & & $\mathrm{x}$ & & & & & & & & & & & & & & & \\
\hline GS-N & ANRT & Granite & $\mathrm{x}$ & $\mathrm{x}$ & $\mathrm{x}$ & $\mathrm{x}$ & $\mathrm{x}$ & $\mathrm{x}$ & $\mathrm{x}$ & & $\mathrm{x}$ & $\mathrm{x}$ & $\mathrm{x}$ & $\mathrm{x}$ & $\mathrm{x}$ & $\mathrm{x}$ & $\mathrm{x}$ & $\mathrm{x}$ & $\mathrm{x}$ & $\mathrm{x}$ & $\mathrm{x}$ & $\mathrm{x}$ & $\mathrm{x}$ & $\mathrm{x}$ & $\mathrm{x}$ & $\mathrm{x}$ & $\mathrm{x}$ & $\mathrm{x}$ & $\mathrm{x}$ \\
\hline GSP-2 & USGS & Granodiorite & $\mathrm{x}$ & $\mathrm{x}$ & $\mathrm{x}$ & $\mathrm{x}$ & $\mathrm{x}$ & $\mathrm{x}$ & $\mathrm{x}$ & & $\mathrm{x}$ & $\mathrm{x}$ & $\mathrm{x}$ & $\mathrm{x}$ & $\mathrm{x}$ & $\mathrm{x}$ & $\mathrm{x}$ & $\mathrm{x}$ & $\mathrm{x}$ & $\mathrm{x}$ & $\mathrm{x}$ & $\mathrm{x}$ & $\mathrm{x}$ & $\mathrm{x}$ & $\mathrm{x}$ & $\mathrm{x}$ & $\mathrm{x}$ & $\mathrm{x}$ & $\mathrm{x}$ \\
\hline GSR-3 & IGGE & Rock & $\mathrm{x}$ & $\mathrm{x}$ & $\mathrm{x}$ & $\mathrm{x}$ & $\mathrm{x}$ & $\mathrm{x}$ & $\mathrm{x}$ & & $\mathrm{x}$ & $\mathrm{x}$ & $\mathrm{x}$ & $\mathrm{x}$ & $\mathrm{x}$ & $\mathrm{x}$ & $\mathrm{x}$ & $\mathrm{x}$ & $\mathrm{x}$ & $\mathrm{x}$ & $\mathrm{x}$ & $\mathrm{x}$ & $\mathrm{x}$ & $x$ & $\mathrm{x}$ & $\mathrm{x}$ & $\mathrm{x}$ & & $\mathrm{x}$ \\
\hline GSR-4 & IGGE & Rock & $\mathrm{x}$ & $\mathrm{x}$ & $\mathrm{x}$ & $\mathrm{x}$ & $\mathrm{x}$ & $\mathrm{x}$ & $\mathrm{x}$ & & $\mathrm{x}$ & $\mathrm{x}$ & $\mathrm{x}$ & $\mathrm{x}$ & $\mathrm{x}$ & $\mathrm{x}$ & $\mathrm{x}$ & $\mathrm{x}$ & $\mathrm{x}$ & $\mathrm{x}$ & $\mathrm{x}$ & $\mathrm{x}$ & $\mathrm{x}$ & $\mathrm{x}$ & $\mathrm{x}$ & $\mathrm{x}$ & $\mathrm{x}$ & $\mathrm{x}$ & $\mathrm{x}$ \\
\hline GSS-2 & IGGE & Soil & $\mathrm{x}$ & $\mathrm{x}$ & $\mathrm{x}$ & $\mathrm{x}$ & $\mathrm{x}$ & $\mathrm{x}$ & $\mathrm{x}$ & & $\mathrm{x}$ & $\mathrm{x}$ & $\mathrm{x}$ & $\mathrm{x}$ & $\mathrm{x}$ & $\mathrm{x}$ & $\mathrm{x}$ & $\mathrm{x}$ & $\mathrm{x}$ & $\mathrm{x}$ & $\mathrm{x}$ & $\mathrm{x}$ & $\mathrm{x}$ & $\mathrm{x}$ & $\mathrm{x}$ & $\mathrm{x}$ & $\mathrm{x}$ & $\mathrm{x}$ & $\mathrm{x}$ \\
\hline GSS-7 & IGGE & Soil & $\mathrm{x}$ & $\mathrm{x}$ & $\mathrm{x}$ & $\mathrm{x}$ & $\mathrm{x}$ & $\mathrm{x}$ & $\mathrm{x}$ & & $\mathrm{x}$ & $x$ & $\mathrm{x}$ & $\mathrm{x}$ & $\mathrm{x}$ & $\mathrm{x}$ & $\mathrm{x}$ & $\mathrm{x}$ & $\mathrm{x}$ & $\mathrm{x}$ & $\mathrm{x}$ & $\mathrm{x}$ & $\mathrm{x}$ & $\mathrm{x}$ & $\mathrm{x}$ & $\mathrm{x}$ & $\mathrm{x}$ & $\mathrm{x}$ & $\mathrm{x}$ \\
\hline JB-2 & GSJ & Basalt & $\mathrm{x}$ & $\mathrm{x}$ & $\mathrm{x}$ & $\mathrm{x}$ & $\mathrm{x}$ & $\mathrm{x}$ & $\mathrm{x}$ & & $\mathrm{x}$ & $x$ & $\mathrm{x}$ & $\mathrm{x}$ & $\mathrm{x}$ & $\mathrm{x}$ & $x$ & $\mathrm{x}$ & $\mathrm{x}$ & $\mathrm{x}$ & $\mathrm{x}$ & $\mathrm{x}$ & $x$ & $x$ & $\mathrm{x}$ & $x$ & $\mathrm{x}$ & $\mathrm{x}$ & $\mathrm{x}$ \\
\hline Mica-Fe & CRPG & Biotite & $\mathrm{x}$ & $\mathrm{x}$ & $\mathrm{x}$ & $\mathrm{x}$ & & $\mathrm{x}$ & $\mathrm{x}$ & & $\mathrm{x}$ & $\mathrm{x}$ & $\mathrm{x}$ & $x$ & $\mathrm{x}$ & $\mathrm{x}$ & $\mathrm{x}$ & $\mathrm{x}$ & $\mathrm{x}$ & & $\mathrm{x}$ & $\mathrm{x}$ & $\mathrm{x}$ & $\mathrm{x}$ & $\mathrm{x}$ & $\mathrm{x}$ & $\mathrm{x}$ & $\mathrm{x}$ & $\mathrm{x}$ \\
\hline SARM1 & MINTEK & NIM-G Granite & $\mathrm{x}$ & & $\mathrm{x}$ & $\mathrm{x}$ & & $\mathrm{x}$ & $\mathrm{x}$ & & $\mathrm{x}$ & & $\mathrm{x}$ & $\mathrm{x}$ & & & & $\mathrm{x}$ & $\mathrm{x}$ & $\mathrm{x}$ & $\mathrm{x}$ & $\mathrm{x}$ & $\mathrm{x}$ & & & $\mathrm{x}$ & $\mathrm{x}$ & $\mathrm{x}$ & $\mathrm{x}$ \\
\hline SARM2 & MINTEK & NIM-S Syenite & $\mathrm{x}$ & $\mathrm{x}$ & $\mathrm{x}$ & $\mathrm{x}$ & $\mathrm{x}$ & $\mathrm{x}$ & $\mathrm{x}$ & & $\mathrm{x}$ & $\mathrm{x}$ & $\mathrm{x}$ & $\mathrm{x}$ & $\mathrm{x}$ & & & $\mathrm{x}$ & & $\mathrm{x}$ & $\mathrm{x}$ & & & & & $\mathrm{x}$ & & & $\mathrm{x}$ \\
\hline SARM39 & MINTEK & Kimberlite & & $\mathrm{x}$ & $\mathrm{x}$ & $\mathrm{x}$ & $\mathrm{x}$ & $\mathrm{x}$ & & $\mathrm{x}$ & $\mathrm{x}$ & $\mathrm{x}$ & $\mathrm{x}$ & $\mathrm{x}$ & & $\mathrm{x}$ & & $\mathrm{x}$ & $\mathrm{x}$ & $\mathrm{x}$ & & $\mathrm{x}$ & $\mathrm{x}$ & $\mathrm{x}$ & & & & & \\
\hline SARM3 & MINTEK & NIM-L Lujavrite & & $\mathrm{x}$ & $\mathrm{x}$ & $\mathrm{x}$ & $\mathrm{x}$ & $\mathrm{x}$ & $\mathrm{x}$ & & $\mathrm{x}$ & $\mathrm{x}$ & & $\mathrm{x}$ & $\mathrm{x}$ & & & $\mathrm{x}$ & $\mathrm{x}$ & $\mathrm{x}$ & $\mathrm{x}$ & $\mathrm{x}$ & & $\mathrm{x}$ & & & & $\mathrm{x}$ & \\
\hline SARM5 & MINTEK & NIM-P Pyroxenite & $\mathrm{x}$ & $\mathrm{x}$ & $\mathrm{x}$ & $\mathrm{x}$ & $\mathrm{x}$ & $\mathrm{x}$ & $\mathrm{x}$ & & $\mathrm{x}$ & & & $\mathrm{x}$ & $\mathrm{x}$ & $\mathrm{x}$ & $\mathrm{x}$ & $\mathrm{x}$ & $\mathrm{x}$ & & $\mathrm{x}$ & & & & & & & & \\
\hline SARM52 & MINTEK & Stream sediment & & $\mathrm{x}$ & $\mathrm{x}$ & $\mathrm{x}$ & $\mathrm{x}$ & $\mathrm{x}$ & $\mathrm{x}$ & & $\mathrm{x}$ & $\mathrm{x}$ & & $\mathrm{x}$ & & $\mathrm{x}$ & & $\mathrm{x}$ & $\mathrm{x}$ & $\mathrm{x}$ & $\mathrm{x}$ & $\mathrm{x}$ & $\mathrm{x}$ & & & & & $\mathrm{x}$ & $\mathrm{x}$ \\
\hline SGR1 & USGS & Green river shale & $\mathrm{x}$ & $\mathrm{x}$ & $\mathrm{x}$ & $\mathrm{x}$ & & $\mathrm{x}$ & & $\mathrm{x}$ & $\mathrm{x}$ & $\mathrm{x}$ & $\mathrm{x}$ & $\mathrm{x}$ & $\mathrm{x}$ & $\mathrm{x}$ & & $\mathrm{x}$ & $\mathrm{x}$ & & $\mathrm{x}$ & & & $\mathrm{x}$ & $\mathrm{x}$ & $\mathrm{x}$ & $\mathrm{x}$ & $\mathrm{x}$ & $x$ \\
\hline SL1 & IAEA & Lake sediment & $\mathrm{x}$ & & & & & & & & $\mathrm{x}$ & $\mathrm{x}$ & $\mathrm{x}$ & & $\mathrm{x}$ & $\mathrm{x}$ & $\mathrm{x}$ & $\mathrm{x}$ & $\mathrm{x}$ & $\mathrm{x}$ & & & & $\mathrm{x}$ & $\mathrm{x}$ & $\mathrm{x}$ & $\mathrm{x}$ & $\mathrm{x}$ & $\mathrm{x}$ \\
\hline SRM278 & NBS & Obsidian Rock & $\mathrm{x}$ & & $\mathrm{x}$ & $\mathrm{x}$ & $\mathrm{x}$ & $\mathrm{x}$ & $\mathrm{x}$ & & $\mathrm{x}$ & & & $\mathrm{x}$ & $\mathrm{x}$ & & $\mathrm{x}$ & $\mathrm{x}$ & & $\mathrm{x}$ & $\mathrm{x}$ & & & & & & & $\mathrm{x}$ & $\mathrm{x}$ \\
\hline Sco1 & USGS & Cody shale & $\mathrm{x}$ & $\mathrm{x}$ & $\mathrm{x}$ & $\mathrm{x}$ & $\mathrm{x}$ & $\mathrm{x}$ & $\mathrm{x}$ & & $\mathrm{x}$ & $\mathrm{x}$ & $\mathrm{x}$ & $\mathrm{x}$ & $\mathrm{x}$ & $\mathrm{x}$ & $\mathrm{x}$ & $\mathrm{x}$ & $\mathrm{x}$ & $\mathrm{x}$ & $\mathrm{x}$ & $\mathrm{x}$ & $\mathrm{x}$ & $\mathrm{x}$ & $\mathrm{x}$ & $\mathrm{x}$ & $\mathrm{x}$ & $\mathrm{x}$ & $\mathrm{x}$ \\
\hline
\end{tabular}




\begin{tabular}{|c|c|c|c|c|c|c|c|c|c|c|c|c|c|c|c|c|c|c|c|c|c|c|c|c|c|c|c|c|c|}
\hline Soil7 & IAEA & Soil & $\mathrm{x}$ & $\mathrm{x}$ & $\mathrm{x}$ & $\mathbf{3}$ & & $\mathrm{x}$ & - & $\mathrm{x}$ & $\mathrm{x}$ & $\mathrm{x}$ & $\mathrm{x}$ & $\mathrm{x}$ & $\mathrm{x}$ & $\mathrm{x}$ & & $\mathrm{x}$ & $\mathrm{x}$ & $\mathrm{x}$ & $\mathrm{x}$ & $\mathrm{x}$ & $\mathrm{x}$ & $\mathrm{x}$ & $\mathrm{x}$ & $\mathrm{x}$ & $\mathrm{x}$ & $\mathrm{x}$ & $\mathrm{x}$ \\
\hline UB-N & ANRT & Serpentine & $\mathrm{x}$ & $\mathrm{x}$ & $\mathrm{x}$ & $\mathrm{x}$ & $\mathrm{x}$ & $\mathrm{x}$ & $\mathrm{x}$ & $\mathbf{2}$ & $\mathrm{x}$ & $\mathrm{x}$ & $\mathrm{x}$ & $\mathrm{x}$ & $\mathrm{x}$ & $\mathrm{x}$ & $\mathrm{x}$ & $\mathrm{x}$ & $\mathrm{x}$ & $\mathrm{x}$ & $\mathrm{x}$ & $\mathrm{x}$ & $\mathrm{x}$ & $\mathrm{x}$ & $\mathrm{x}$ & $\mathrm{x}$ & $\mathrm{x}$ & $\mathrm{x}$ & \\
\hline W-2 & USGS & Diabase & $\mathrm{x}$ & $\mathrm{x}$ & $\mathrm{x}$ & $\mathrm{x}$ & $\mathrm{x}$ & $\mathrm{x}$ & $\mathbf{2}$ & $\mathrm{x}$ & $\mathrm{x}$ & $\mathrm{x}$ & $\mathrm{x}$ & $\mathrm{x}$ & $\mathrm{x}$ & $\mathrm{x}$ & $\mathrm{x}$ & $\mathrm{x}$ & $\mathrm{x}$ & $\mathrm{x}$ & $\mathrm{x}$ & $\mathrm{x}$ & $\mathrm{x}$ & $\mathrm{x}$ & $\mathrm{x}$ & $\mathrm{x}$ & $\mathrm{x}$ & $\mathrm{x}$ \\
\hline WS-E & GIT/IWT & Dolerite & $\mathrm{x}$ & $\mathrm{x}$ & $\mathrm{x}$ & $\mathrm{x}$ & $\mathrm{x}$ & $\mathrm{x}$ & $\mathrm{x}$ & $\mathbf{2}$ & $\mathrm{x}$ & $\mathrm{x}$ & $\mathrm{x}$ & $\mathrm{x}$ & $\mathrm{x}$ & $\mathrm{x}$ & $\mathrm{x}$ & $\mathrm{x}$ & $\mathrm{x}$ & $\mathrm{x}$ & $\mathrm{x}$ & $\mathrm{x}$ & $\mathrm{x}$ & $\mathrm{x}$ & $\mathrm{x}$ & $\mathrm{x}$ & $\mathrm{x}$ & $\mathrm{x}$ & $\mathrm{x}$ \\
\hline
\end{tabular}

Table 1. CRMs used in calibration (cells with x: included in calibration line; grey cells: not used in calibration line as it was not certified for this element; diagonal stripe cells: not included in calibration line for other reasons)

\begin{tabular}{|c|c|c|c|c|c|c|c|c|c|c|c|c|c|c|c|}
\hline El. & Line & $\begin{array}{l}\mathrm{V}(\mathrm{kV}) / \\
\mathrm{C}(\mathrm{mA})\end{array}$ & Filter & Crystal & $\begin{array}{l}\text { Detector/ } \\
\text { Collim. }\end{array}$ & $\begin{array}{l}\text { LLD- } \\
\text { ULD }\end{array}$ & Peak $\left({ }^{\circ} 2 \theta\right)$ & $\operatorname{Bkg} 1\left({ }^{\circ} 2 \theta\right)$ & $\operatorname{Bkg} 2\left({ }^{\circ} 2 \theta\right)$ & $\begin{array}{l}\operatorname{Max} \\
\mathrm{Ct} \mathrm{t} \\
(\mathrm{s})\end{array}$ & $\begin{array}{l}\text { CSE } \\
(\%)\end{array}$ & $\begin{array}{l}\text { Bkg time } \\
\text { control }^{1}\end{array}$ & $\begin{array}{l}\text { \# stds (Range of } \\
\left.\text { stds comp }{ }^{2}\right)\end{array}$ & $\begin{array}{l}\text { Overlap } \\
\text { correction }\end{array}$ & $\overline{\mathrm{R}^{2}}$ \\
\hline $\mathrm{Na}$ & KA1 & $30 / 120$ & None & XS-55 & $\begin{array}{l}\text { Flow/ } \\
0.46^{\circ}\end{array}$ & $60-160$ & 25.104 & 26.825 & & 16 & 1 & Opt. & $30(0.03-5.19 \%)$ & $\mathrm{Mg} \mathrm{Ka}$ & 1.00 \\
\hline $\mathrm{Mg}$ & KA1 & $30 / 120$ & None & XS-55 & $\begin{array}{l}\text { Flow/ } \\
0.23^{\circ}\end{array}$ & $40-160$ & 20.834 & 22.951 & & 16 & 1 & Opt. & $29(0.08-44.61 \%)$ & $\mathrm{Al} \mathrm{Ka}$ & 1.00 \\
\hline $\mathrm{Al}$ & KA1 & $30 / 120$ & None & PET & $\begin{array}{l}\text { Flow/ } \\
0.46^{\circ}\end{array}$ & $40-160$ & 144.665 & 138.475 & & 20 & 0.5 & Opt. & $33(0.19-34.24 \%)$ & $\mathrm{Br} \mathrm{La}$ & 1.00 \\
\hline $\mathrm{Si}$ & KA1 & $30 / 45$ & None & PET & $\begin{array}{l}\text { Flow/ } \\
0.46^{\circ}\end{array}$ & $40-160$ & 108.999 & 112.599 & & 12 & 0.5 & Opt. & $32(1.17-91.53 \%)$ & - & 1.00 \\
\hline $\mathrm{P}$ & KA1 & $30 / 120$ & None & $\mathrm{Ge}$ & $\begin{array}{l}\text { Flow/ } \\
0.46^{\circ}\end{array}$ & $50-150$ & 140.953 & 143.367 & & 30 & 1 & Opt. & $29(0.00-1.63 \%)$ & - & 1.00 \\
\hline $\mathrm{K}$ & KA1 & $50 / 65$ & None & LiF200 & $\begin{array}{l}\text { Flow/ } \\
0.46^{\circ}\end{array}$ & $50-150$ & 136.681 & 139.610 & & 20 & 1 & Opt. & $33(0.01-15.46 \%)$ & - & 1.00 \\
\hline $\mathrm{Ca}$ & $\mathrm{KA} 1_{\text {Min }}$ & $50 / 65$ & None & LiF200 & $\begin{array}{l}\text { Flow/ } \\
0.46^{\circ}\end{array}$ & $70-130$ & 113.112 & 115.000 & & 30 & 1 & Opt. & $24(0.11-9.80 \%)$ & - & 1.00 \\
\hline $\mathrm{Ca}$ & KA1 Maj & $50 / 12$ & None & LiF200 & $\begin{array}{l}\text { Flow/ } \\
0.46^{\circ}\end{array}$ & $70-300$ & 113.112 & 115.000 & & 16 & 0.3 & Opt. & $8(10.81-29.26 \%)$ & - & 1.00 \\
\hline $\mathrm{Ti}$ & KA1 & $50 / 65$ & None & LiF200 & $\begin{array}{l}\text { Flow/ } \\
0.23^{\circ}\end{array}$ & $70-140$ & 86.155 & 84.601 & 88.419 & 30 & off & Fixed & $42(0.00-3.94 \%)$ & $\begin{array}{l}\text { Ba La } \\
\text { (conc.) }\end{array}$ & 1.00 \\
\hline $\mathrm{V}$ & KA1 & $50 / 81$ & None & LiF220 & $\begin{array}{l}\text { Flow/ } \\
0.23^{\circ}\end{array}$ & $70-140$ & 123.227 & 121.666 & 126.000 & 90 & off & Fixed & 38 (1-824 ppm) & $\begin{array}{l}\mathrm{Ti} \mathrm{Kb}, \mathrm{Ba} \\
\mathrm{Lb}\end{array}$ & 1.00 \\
\hline $\mathrm{Cr}$ & KA1 & $60 / 67$ & None & LiF220 & $\begin{array}{l}\text { Flow/ } \\
0.23^{\circ}\end{array}$ & $70-140$ & 107.141 & 105.204 & 108.991 & 120 & off & Fixed & $36(4-3350 \mathrm{ppm})$ & $\mathrm{V} \mathrm{Kb}$ & 1.00 \\
\hline $\mathrm{Mn}$ & KA1 & $60 / 67$ & None & LiF220 & $\begin{array}{l}\text { Flow/ } \\
0.23^{\circ}\end{array}$ & $75-135$ & 95.217 & 92.851 & 97.141 & 30 & off & Fixed & $\begin{array}{l}41(39- \\
16770 \mathrm{ppm})\end{array}$ & $\mathrm{Cr} \mathrm{Kb}$ & 1.00 \\
\hline $\mathrm{Fe}$ & KA1 & $60 / 50$ & $\mathrm{Al} 200 \mu \mathrm{m}$ & LiF220 & $\begin{array}{l}\text { Scint./ } \\
0.23^{\circ}\end{array}$ & $40-160$ & 85.718 & 87.595 & & 30 & 0.5 & Opt. & $30(0.09-26.13 \%)$ & $\mathrm{Mn} \mathrm{Kb}$ & 1.00 \\
\hline
\end{tabular}

${ }^{1}$ For fixed: background measurement time = peak measurement time

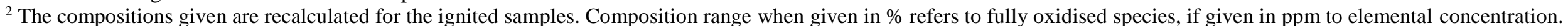




\begin{tabular}{|c|c|c|c|c|c|c|c|c|c|c|c|c|c|c|c|}
\hline Co & KA1 & $60 / 67$ & $\mathrm{Al} 200 \mu \mathrm{m}$ & LiF200 & $\begin{array}{l}\text { Scint./ } \\
0.23^{\circ}\end{array}$ & $50-140$ & 52.762 & 50.538 & 54.750 & 120 & off & Fixed & 36 (4-336ppm) & $\begin{array}{l}\mathrm{Fe} \mathrm{Kb}, \mathrm{Sr} \mathrm{Ka} \\
\left(2^{\text {nd }}\right), \mathrm{Rb} \mathrm{Ka} \\
\left(2^{\text {nd }}\right)\end{array}$ & 1.00 \\
\hline $\mathrm{Ni}$ & KA1 & $60 / 67$ & $\mathrm{Al} 200 \mu \mathrm{m}$ & LiF200 & $\begin{array}{l}\text { Scint./ } \\
0.46^{\circ}\end{array}$ & $50-150$ & 48.684 & 47.890 & 49.517 & 120 & off & Fixed & $33(2-2745$ ppm) & $\mathrm{Co} \mathrm{Kb}$ & 1.00 \\
\hline $\mathrm{Cu}$ & KA1 & $60 / 67$ & $\mathrm{Al} 1500 \mu \mathrm{m}$ & LiF200 & $\begin{array}{l}\text { Scint./ } \\
0.23^{\circ}\end{array}$ & $50-150$ & 45.026 & 44.449 & 46.698 & 120 & off & Fixed & $38(2-824 \mathrm{ppm})$ & $\mathrm{Ni} \mathrm{Ka}$ & 0.99 \\
\hline $\mathrm{Zn}$ & KA1 & $60 / 67$ & $\mathrm{Al} 500 \mu \mathrm{m}$ & LiF200 & \begin{tabular}{|l} 
Scint./ \\
$0.23^{\circ}$ \\
\end{tabular} & $60-140$ & 41.806 & 41.229 & 42.325 & 90 & off & Fixed & 37 (5-1324 ppm) & $\begin{array}{l}\mathrm{Cu} \mathrm{Kb}, \mathrm{Zr} \\
\mathrm{Kb}\left(2^{\text {nd }}\right)\end{array}$ & 1.00 \\
\hline $\mathrm{Rb}$ & KA1 & $60 / 67$ & $\mathrm{Al} 800 \mu \mathrm{m}$ & LiF220 & \begin{tabular}{|l} 
Scint./ \\
$0.23^{\circ}$ \\
\end{tabular} & $60-130$ & 37.975 & 35.082 & 39.578 & 40 & off & Fixed & $26(5-863 \mathrm{ppm})$ & $\mathrm{Br} \mathrm{Kb}$ & 1.00 \\
\hline $\mathrm{Sr}$ & KA1 & $60 / 67$ & $\mathrm{Al} 800 \mu \mathrm{m}$ & LiF220 & $\begin{array}{l}\text { Scint./ } \\
0.23^{\circ}\end{array}$ & $60-130$ & 35.836 & 35.082 & 39.578 & 40 & off & Fixed & $39(5-8470$ ppm $)$ & $\mathrm{Zr} \mathrm{Ka}, \mathrm{Pb} \mathrm{Lg}$ & 1.00 \\
\hline $\mathrm{Y}$ & KA1 & $60 / 67$ & $\mathrm{Al} 1800 \mu \mathrm{m}$ & LiF220 & \begin{tabular}{|l} 
Scint./ \\
$0.46^{\circ}$
\end{tabular} & $60-126$ & 33.867 & 33.032 & 34.616 & 120 & off & Fixed & 33 (1-336 ppm) & $\begin{array}{l}\mathrm{Rb} \mathrm{Kb}, \mathrm{Br} \\
\mathrm{Kb}, \mathrm{Pb} \mathrm{Lg}\end{array}$ & 1.00 \\
\hline $\mathrm{Zr}$ & KA1 & $60 / 67$ & $\mathrm{Al} 800 \mu \mathrm{m}$ & LiF220 & $\begin{array}{l}\text { Scint./ } \\
0.23^{\circ}\end{array}$ & $60-140$ & 32.072 & 30.982 & 33.172 & 40 & off & Fixed & $34(0-824$ ppm $)$ & $\mathrm{Sr} \mathrm{Kb}$ & 1.00 \\
\hline $\mathrm{Ba}$ & LA1 & $50 / 81$ & None & LiF200 & \begin{tabular}{|l|} 
Flow/ \\
$0.23^{\circ}$ \\
\end{tabular} & $70-140$ & 87.171 & 84.601 & 88.419 & 60 & off & Fixed & $36(12-8220 \mathrm{ppm})$ & $\begin{array}{l}\text { Ti Ka } \\
\text { (conc.) }\end{array}$ & 1.00 \\
\hline $\mathrm{La}$ & LA1 & $50 / 81$ & $\mathrm{Al} 12.5 \mu \mathrm{m}$ & LiF200 & $\begin{array}{l}\text { Flow/ } \\
0.46^{\circ} \\
\end{array}$ & $70-130$ & 82.948 & 82.165 & 84.072 & 360 & off & Fixed & $26(0-204 \mathrm{ppm})$ & $\begin{array}{l}\text { Nd Ll, Ti } \\
\text { Ka, Ba La }\end{array}$ & 1.00 \\
\hline $\mathrm{Ce}$ & LA1 & $50 / 81$ & $\mathrm{Al1} 2.5 \mu \mathrm{m}$ & LiF200 & $\begin{array}{l}\text { Flow/ } \\
0.23^{\circ}\end{array}$ & $65-135$ & 79.035 & 78.412 & 79.944 & 360 & off & Fixed & $35(0-824 \mathrm{ppm})$ & $\begin{array}{l}\mathrm{Ba} \mathrm{Lb}, \mathrm{Ti} \\
\mathrm{Kb}\end{array}$ & 1.00 \\
\hline $\mathrm{Nd}$ & LA1 & $60 / 67$ & $\mathrm{Al} 12.5 \mu \mathrm{m}$ & LiF200 & \begin{tabular}{|l|} 
Flow/ \\
$0.23^{\circ}$ \\
\end{tabular} & $70-130$ & 72.136 & 70.905 & 74.163 & 360 & off & Fixed & $27(0-220 \mathrm{ppm})$ & $\begin{array}{l}\mathrm{Ce} \mathrm{Lb}, \mathrm{Ba} \\
\mathrm{Lb}\end{array}$ & 1.00 \\
\hline $\mathrm{Pb}$ & LB1 & $60 / 67$ & $\mathrm{Al} 800 \mu \mathrm{m}$ & LiF200 & $\begin{array}{l}\text { Scint./ } \\
0.23^{\circ}\end{array}$ & $55-135$ & 28.257 & 27.861 & 28.649 & 240 & off & Fixed & 28 (4-1311 ppm) & - & 1.00 \\
\hline Th & LA1 & $60 / 67$ & $\mathrm{Al} 800 \mu \mathrm{m}$ & LiF220 & \begin{tabular}{|l} 
Scint./ \\
$0.23^{\circ}$ \\
\end{tabular} & $60-120$ & 39.241 & 38.884 & 39.578 & 360 & off & Fixed & $24(0-153 \mathrm{ppm})$ & $\mathrm{Pb} \mathrm{Lb}$ & 1.00 \\
\hline $\mathrm{Br}$ & KA1 & $60 / 67$ & $\mathrm{Al} 500 \mu \mathrm{m}$ & LiF220 & $\begin{array}{l}\text { Scint./ } \\
0.23^{\circ}\end{array}$ & $50-150$ & 42.871 & 42.172 & 43.742 & 30 & 0.3 & Opt. & & & N/A \\
\hline
\end{tabular}

Table 2: Line parameters and coefficients of determination deduced from relevant calibration lines for each element.

\begin{tabular}{|l|r|r|r|r|r|}
\hline & \multicolumn{3}{|c|}{ LLD } & LOD & LOQ \\
\hline & Mean & Min & Max & Mean & Mean \\
\hline $\mathrm{Na}_{2} \mathrm{O}$ & 86 & 72 & 119 & 173 & 288 \\
\hline $\mathrm{MgO}$ & 93 & 70 & 106 & 185 & 309 \\
\hline $\mathrm{Al}_{2} \mathrm{O}_{3}$ & 45 & 34 & 58 & 89 & 149 \\
\hline $\mathrm{SiO}_{2}$ & 98 & 74 & 110 & 196 & 326 \\
\hline
\end{tabular}




\begin{tabular}{|l|r|r|r|r|r|}
$\mathrm{P}_{2} \mathrm{O}_{5}$ & 13 & 10 & 14 & 25 & 42 \\
\hline $\mathrm{K}_{2} \mathrm{O}$ & 13 & 9 & 21 & 26 & 43 \\
\hline $\mathrm{CaO}$ & 20 & 8 & 48 & 40 & 66 \\
\hline $\mathrm{TiO}_{2}$ & 22 & 19 & 24 & 44 & 73 \\
\hline $\mathrm{V}$ & 7 & 5 & 9 & 15 & 24 \\
\hline $\mathrm{Cr}$ & 5 & 5 & 6 & 11 & 18 \\
\hline $\mathrm{Mn}$ & 10 & 8 & 11 & 19 & 32 \\
\hline $\mathrm{Fe}_{2} \mathrm{O}_{3}$ & 41 & 25 & 64 & 82 & 137 \\
\hline $\mathrm{Co}$ & 3 & 2 & 4 & 6 & 10 \\
\hline $\mathrm{Ni}$ & 2 & 1 & 2 & 3 & 5 \\
\hline $\mathrm{Cu}$ & 2 & 2 & 3 & 4 & 7 \\
\hline $\mathrm{Zn}$ & 2 & 2 & 2 & 3 & 6 \\
\hline $\mathrm{Rb}$ & 4 & 3 & 5 & 8 & 13 \\
\hline $\mathrm{Sr}$ & 2 & 2 & 3 & 4 & 7 \\
\hline $\mathrm{Y}$ & 1 & 1 & 2 & 3 & 5 \\
\hline $\mathrm{Zr}$ & 3 & 2 & 3 & 5 & 8 \\
\hline $\mathrm{Ba}$ & 24 & 19 & 29 & 49 & 81 \\
\hline $\mathrm{La}$ & 6 & 5 & 7 & 12 & 21 \\
\hline $\mathrm{Ce}$ & 9 & 7 & 10 & 17 & 29 \\
\hline $\mathrm{Nd}$ & 5 & 5 & 6 & 11 & 18 \\
\hline $\mathrm{Pb}$ & 2 & 2 & 3 & 5 & 8 \\
\hline $\mathrm{Th}$ & 2 & 1 & 2 & 3 & 5 \\
\hline
\end{tabular}

Table 3: Lower limits of detection, limits of determination and limits of quantification in ppm for each element calculated by averaging the estimates from the analysis of the nine CRMs and six reference materials analysed in this study. For the LLDs additionally the minimum and maximum LLDs are given for the fifteen samples, to indicate the variability due to matrix effects.

\begin{tabular}{|c|c|c|c|c|c|c|c|c|c|c|c|c|c|c|c|c|c|c|}
\hline & \multicolumn{2}{|c|}{ GSR-1 } & \multicolumn{2}{|c|}{ PM-S } & \multicolumn{2}{|c|}{ GBW07307a } & \multicolumn{2}{|c|}{ GBW07311 } & \multicolumn{2}{|c|}{ IPT 32} & \multicolumn{2}{|c|}{ Kaolin KK } & \multicolumn{2}{|c|}{ SRM2711a } & \multicolumn{2}{|c|}{ SRM679 } & \multicolumn{2}{|c|}{ SO-3 } \\
\hline & mean & $\mathrm{CV}$ & mean & $\mathrm{CV}$ & mean & $\mathrm{CV}$ & mean & CV & mean & $\mathrm{CV}$ & mean & $\mathrm{CV}$ & mean & $\mathrm{CV}$ & mean & $\mathrm{CV}$ & mean & $\mathrm{CV}$ \\
\hline $\mathrm{Na}_{2} \mathrm{O}$ & 3.17 & 0.3 & 2.14 & 0.4 & 2.36 & 0.3 & 0.47 & 1.4 & 0.20 & 2.7 & 0.06 & 10.9 & 1.67 & 0.4 & 0.21 & 1.5 & 0.97 & 0.7 \\
\hline $\mathrm{MgO}$ & 0.42 & 1.3 & 9.40 & 0.2 & 2.49 & 0.4 & 0.64 & 0.9 & 0.42 & 1.0 & 0.27 & 1.7 & 1.72 & 0.5 & 1.31 & 0.4 & 8.43 & 0.3 \\
\hline $\mathrm{Al}_{2} \mathrm{O}_{3}$ & 13.36 & 0.1 & 17.13 & 0.1 & 11.04 & 0.2 & 10.58 & 0.1 & 28.56 & 0.1 & 36.65 & 0.2 & 12.73 & 0.1 & 20.79 & 0.1 & 5.71 & 0.2 \\
\hline $\mathrm{SiO}_{2}$ & 73.55 & 0.1 & 47.21 & 0.2 & 67.24 & 0.1 & 76.11 & 0.1 & 51.68 & 0.2 & 46.57 & 0.2 & 66.34 & 0.1 & 52.14 & 0.1 & 33.77 & 0.2 \\
\hline
\end{tabular}




\begin{tabular}{|c|c|c|c|c|c|c|c|c|c|c|c|c|c|c|c|c|c|c|}
\hline $\mathrm{P}_{2} \mathrm{O}_{5}$ & 0.09 & 1.0 & 0.03 & 2.0 & 0.14 & 1.1 & 0.05 & 1.6 & 0.11 & 1.2 & 0.08 & 1.1 & 0.19 & 0.4 & 0.16 & 0.6 & 0.10 & 0.9 \\
\hline $\mathrm{K}_{2} \mathrm{O}$ & 4.98 & 0.1 & 0.14 & 0.0 & 1.76 & 0.2 & 3.14 & 0.1 & 0.84 & 0.0 & 1.14 & 0.4 & 3.06 & 0.1 & 2.91 & 0.2 & 1.34 & 0.0 \\
\hline $\mathrm{CaO}$ & 1.54 & 0.3 & 12.47 & 0.3 & 2.92 & 0.2 & 0.47 & 0.0 & 0.19 & 0.0 & 0.28 & 0.0 & 3.39 & 0.2 & 0.24 & 2.0 & 20.57 & 0.2 \\
\hline $\mathrm{TiO}_{2}$ & 0.29 & 1.1 & 1.11 & 0.2 & 0.67 & 0.4 & 0.35 & 0.5 & 1.52 & 0.3 & 0.18 & 0.6 & 0.53 & 0.5 & 0.98 & 0.2 & 0.32 & 0.5 \\
\hline $\mathrm{V}$ & 22 & 13.6 & 189 & 1.7 & 75 & 4.5 & 45 & 8.3 & 88 & 4.4 & 20 & 13.8 & 83 & 3.0 & 164 & 2.0 & 34 & 4.1 \\
\hline $\mathrm{Cr}$ & 7 & 27.9 & 308 & 0.9 & 46 & 6.1 & 40 & 9.1 & 58 & 3.3 & 12 & 30.9 & 120 & 1.9 & 108 & 3.4 & 28 & 6.7 \\
\hline $\mathrm{Mn}$ & 474 & 1.0 & 1227 & 0.6 & 883 & 1.0 & 2569 & 0.3 & 115 & 5.0 & 112 & 5.1 & 692 & 1.3 & 1784 & 0.5 & 538 & 1.1 \\
\hline $\mathrm{Fe}_{2} \mathrm{O}_{3}$ & 1.92 & 0.4 & 10.08 & 0.1 & 4.12 & 0.2 & 4.28 & 0.2 & 3.43 & 0.2 & 0.98 & 0.5 & 4.12 & 0.2 & 13.03 & 0.2 & 2.16 & 0.2 \\
\hline Co & 5 & 26.2 & 49 & 2.8 & 17 & 7.7 & 9 & 14.0 & 6 & 15.7 & 3 & 30.5 & 11 & 7.7 & 25 & 4.5 & 5 & 23.6 \\
\hline $\mathrm{Ni}$ & 5 & 12.7 & 120 & 0.8 & 24 & 2.7 & 15 & 4.8 & 10 & 9.2 & 2 & 21.0 & 54 & 1.5 & 63 & 1.1 & 11 & $\mid 10.1$ \\
\hline $\mathrm{Cu}$ & 0 & & 62 & 2.9 & 46 & 2.4 & 83 & 1.4 & 16 & 7.5 & 65 & 1.5 & 133 & 0.9 & 37 & 3.9 & 21 & 3.2 \\
\hline $\mathrm{Zn}$ & 23 & 3.5 & 59 & 1.4 & 803 & 0.3 & 385 & 0.4 & 55 & 1.4 & 47 & 2.0 & 417 & 0.3 & 117 & 1.0 & 50 & 1.0 \\
\hline $\mathrm{Rb}$ & 462 & 0.4 & 18 & 0.0 & 48 & 4.5 & 358 & 0.6 & 30 & 5.4 & 160 & 1.3 & 118 & 0.8 & 185 & 0.8 & 32 & 4.1 \\
\hline $\mathrm{Sr}$ & 117 & 0.9 & 271 & 0.7 & 228 & 0.5 & 30 & 4.8 & 86 & 0.8 & 79 & 1.3 & 234 & 0.4 & 80 & 1.9 & 219 & 0.4 \\
\hline$Y$ & 70 & 1.4 & 11 & 7.8 & 14 & 4.5 & 41 & 1.6 & 27 & 1.6 & 22 & 2.6 & 32 & 2.0 & 40 & 2.0 & 16 & 2.0 \\
\hline $\mathrm{Zr}$ & 173 & 0.6 & 36 & 2.2 & 171 & 0.6 & 145 & 1.3 & 660 & 0.3 & 76 & 1.3 & 327 & 0.5 & 155 & 0.9 & 170 & 0.7 \\
\hline $\mathrm{Ba}$ & 325 & 3.8 & 150 & 7.4 & 426 & 3.0 & 252 & 4.3 & 350 & 4.1 & 176 & 3.5 & 718 & 1.8 & 470 & 2.4 & 278 & 3.8 \\
\hline La & 53 & 5.7 & 6 & 38.0 & 26 & 8.7 & 28 & 7.9 & 97 & 3.5 & 57 & 4.9 & 42 & 5.9 & 52 & 4.8 & 17 & 21.7 \\
\hline $\mathrm{Ce}$ & 105 & 3.0 & 5 & 93.4 & 54 & 8.3 & 56 & 6.4 & 143 & 3.3 & 131 & 2.3 & 74 & 6.2 & 101 & 4.3 & 33 & 10.7 \\
\hline $\mathrm{Nd}$ & 46 & 8.6 & 7 & 22.1 & 24 & 8.0 & 28 & 8.3 & 64 & 4.3 & 64 & 2.5 & 34 & 8.0 & 46 & 5.5 & 19 & 12.3 \\
\hline $\mathrm{Pb}$ & 20 & 2.5 & 10 & 0.0 & 530 & 0.2 & 622 & 0.2 & 64 & 1.3 & 138 & 0.5 & 1570 & 0.2 & 26 & 4.2 & 15 & 7.6 \\
\hline Th & 53 & 1.1 & 1 & 0.0 & 7 & 10.1 & 32 & 2.5 & 30 & 3.0 & 25 & 3.1 & 18 & 5.8 & 16 & 4.6 & 3 & 18.3 \\
\hline
\end{tabular}

\begin{tabular}{|l|r|r|r|r|r|r|r|r|r|r|r|r|r|r|}
\hline & \multicolumn{2}{|c|}{ Bonn } & \multicolumn{2}{c|}{ Podmore } & \multicolumn{2}{c|}{ OG18 } & \multicolumn{2}{c|}{ NOR18 } & \multicolumn{2}{c|}{ TF18 } & \multicolumn{2}{c|}{ Pikermi } & Mean \\
\cline { 2 - 17 } & mean & CV & mean & CV & mean & CV & mean & CV & mean & CV & mean & CV & CV \\
\hline $\mathrm{Na}_{2} \mathrm{O}$ & 0.29 & 1.6 & 0.14 & 4.5 & 0.17 & 3.0 & 0.25 & 2.6 & 0.87 & 0.9 & 0.82 & 1.0 & 2.2 \\
\hline $\mathrm{MgO}$ & 0.54 & 0.9 & 0.99 & 0.4 & 0.48 & 0.9 & 1.64 & 0.7 & 0.50 & 0.6 & 1.35 & 0.8 & 0.7 \\
\hline $\mathrm{Al}_{2} \mathrm{O}_{3}$ & 32.39 & 0.1 & 22.20 & 0.1 & 32.38 & 0.1 & 18.41 & 0.1 & 23.59 & 0.1 & 15.06 & 0.1 & 0.1 \\
\hline $\mathrm{SiO}_{2}$ & 58.97 & 0.1 & 53.40 & 0.1 & 59.68 & 0.1 & 65.75 & 0.1 & 69.36 & 0.1 & 41.72 & 0.1 & 0.1 \\
\hline $\mathrm{P}_{2} \mathrm{O}_{5}$ & 0.07 & 1.0 & 0.10 & 1.3 & 0.09 & 0.6 & 0.09 & 1.0 & 0.06 & 1.2 & 0.14 & 0.5 & 1.0 \\
\hline
\end{tabular}




\begin{tabular}{|l|r|r|r|r|r|r|r|r|r|r|r|r|r|}
$\mathrm{K}_{2} \mathrm{O}$ & 1.54 & 0.0 & 1.46 & 0.2 & 1.58 & 0.3 & 4.16 & 0.2 & 1.49 & 0.0 & 1.91 & 0.3 & 0.1 \\
\hline $\mathrm{CaO}$ & 0.28 & 0.0 & 2.59 & 0.2 & 0.17 & 1.8 & 0.20 & 0.0 & 0.34 & 0.0 & 15.04 & 0.1 & 0.4 \\
\hline $\mathrm{TiO}_{2}$ & 1.51 & 0.3 & 1.21 & 0.3 & 2.19 & 0.3 & 1.09 & 0.3 & 1.34 & 0.3 & 0.76 & 0.4 & 0.4 \\
\hline $\mathrm{V}$ & 168 & 1.8 & 168 & 2.2 & 184 & 1.9 & 201 & 1.8 & 128 & 1.4 & 123 & 2.6 & 3.0 \\
\hline $\mathrm{Cr}$ & 127 & 1.9 & 115 & 2.8 & 173 & 2.1 & 83 & 3.8 & 95 & 1.7 & 146 & 1.6 & 3.2 \\
\hline $\mathrm{Mn}$ & 52 & 10.2 & 410 & 1.4 & 22 & 30.3 & 246 & 2.9 & 47 & 9.4 & 797 & 0.8 & 2.9 \\
\hline $\mathrm{Fe}_{2} \mathrm{O}_{3}$ & 1.61 & 0.2 & 7.45 & 0.1 & 1.48 & 0.3 & 7.39 & 0.1 & 1.53 & 0.2 & 6.93 & 0.2 & 0.2 \\
\hline $\mathrm{Co}$ & 20 & 5.9 & 19 & 3.5 & 8 & 13.0 & 23 & 3.6 & 4 & 25.6 & 23 & 4.0 & 5.0 \\
\hline $\mathrm{Ni}$ & 324 & 0.4 & 55 & 0.9 & 32 & 2.2 & 75 & 1.3 & 18 & 4.1 & 122 & 0.8 & 3.7 \\
\hline $\mathrm{Cu}$ & 37 & 3.5 & 26 & 5.3 & 31 & 3.8 & 20 & 6.0 & 7 & 10.7 & 49 & 2.0 & 3.9 \\
\hline $\mathrm{Zn}$ & 79 & 1.3 & 60 & 2.0 & 43 & 1.9 & 91 & 1.2 & 41 & 1.6 & 111 & 1.0 & 1.4 \\
\hline $\mathrm{Rb}$ & 73 & 1.3 & 79 & 3.0 & 98 & 2.3 & 178 & 0.6 & 73 & 1.3 & 89 & 1.3 & 1.9 \\
\hline $\mathrm{Sr}$ & 120 & 1.3 & 105 & 0.8 & 567 & 0.3 & 80 & 1.2 & 179 & 0.7 & 113 & 1.1 & 1.1 \\
\hline $\mathrm{Y}$ & 28 & 2.2 & 34 & 1.4 & 40 & 1.7 & 45 & 1.4 & 32 & 2.1 & 36 & 1.9 & 2.4 \\
\hline $\mathrm{Zr}$ & 209 & 0.6 & 198 & 0.7 & 424 & 0.3 & 257 & 0.4 & 345 & 0.5 & 160 & 0.6 & 0.8 \\
\hline $\mathrm{Ba}$ & 690 & 2.1 & 398 & 2.5 & 359 & 3.2 & 631 & 1.3 & 404 & 1.8 & 229 & 3.6 & 3.3 \\
\hline $\mathrm{La}$ & 49 & 4.7 & 42 & 4.5 & 57 & 3.7 & 53 & 5.6 & 47 & 5.2 & 39 & 4.1 & 5.3 \\
\hline $\mathrm{Ce}$ & 80 & 5.9 & 81 & 5.2 & 107 & 3.9 & 114 & 4.4 & 80 & 4.0 & 65 & 6.2 & 5.3 \\
\hline $\mathrm{Nd}$ & 38 & 5.0 & 38 & 3.5 & 42 & 4.9 & 51 & 4.1 & 36 & 8.8 & 35 & 8.0 & 6.6 \\
\hline $\mathrm{Pb}$ & 33 & 2.0 & 37 & 3.0 & 55 & 2.2 & 15 & 8.8 & 39 & 3.0 & 36 & 2.9 & 2.6 \\
\hline $\mathrm{Th}$ & 15 & 4.9 & 13 & 7.8 & 31 & 1.6 & 17 & 4.3 & 15 & 8.1 & 10 & 9.4 & 5.1 \\
\hline
\end{tabular}

Table 4: Averages (in wt \% for oxides and ppm for elements) and relative standard deviations of ten measurements on each standard. Mean values in Italics are $<$ LOQ in their certified values or the measured values, where certified values are not available. Bold values in average CVs are $>10 \%$ (n.a.: not applicable) 


\begin{tabular}{|c|c|c|c|c|c|c|c|c|c|c|c|c|c|c|c|c|c|c|}
\hline & \multicolumn{6}{|c|}{ GSR-1 } & \multicolumn{6}{|c|}{ PMS } & \multicolumn{6}{|c|}{ GBW07307a } \\
\hline & $x_{r e f}$ & $x_{m n}$ & $x_{m d}$ & $\operatorname{dec}_{l}$ & $d e c_{u p}$ & $x_{m n} / x_{r e f}$ & $x_{r e f}$ & $x_{m n}$ & $x_{m d}$ & $\operatorname{dec}_{l}$ & $\operatorname{dec}_{u p}$ & $x_{m n} / x_{r e f}$ & $x_{r e f}$ & $x_{m n}$ & $x_{m d}$ & $\operatorname{dec}_{l}$ & $\operatorname{dec}_{u p}$ & $x_{m n} / x_{r e f}$ \\
\hline $\mathrm{Na}_{2} \mathrm{O}$ & 3.13 & 3.17 & 3.17 & 3.16 & 3.18 & 1.01 & 2.08 & 2.14 & 2.14 & 2.13 & 2.15 & 1.03 & 2.27 & 2.36 & 2.36 & 2.35 & 2.36 & 1.04 \\
\hline $\mathrm{MgO}$ & 0.42 & 0.42 & 0.42 & 0.41 & 0.42 & 0.99 & 9.34 & 9.40 & 9.40 & 9.38 & 9.42 & 1.01 & 2.50 & 2.49 & 2.49 & 2.49 & 2.50 & 1.00 \\
\hline $\mathrm{Al}_{2} \mathrm{O}_{3}$ & 13.4 & 13.36 & 13.36 & 13.35 & 13.37 & 1.00 & 17.15 & 17.13 & 17.13 & 17.11 & 17.14 & 1.00 & 11.02 & 11.04 & 11.04 & 11.02 & 11.06 & 1.00 \\
\hline $\mathrm{SiO}_{2}$ & 72.83 & 73.55 & 73.55 & 73.48 & 73.61 & 1.01 & 47 & 47.21 & 47.21 & 47.08 & 47.29 & 1.00 & 68.30 & 67.24 & 67.25 & 67.14 & 67.33 & 0.98 \\
\hline $\mathrm{P}_{2} \mathrm{O}_{5}$ & 0.0928 & 0.09 & 0.10 & 0.09 & 0.10 & 1.02 & 0.03 & 0.03 & 0.03 & 0.03 & 0.03 & 0.99 & & 0.14 & 0.14 & 0.14 & 0.14 & \\
\hline $\mathrm{K}_{2} \mathrm{O}$ & 5.01 & 4.98 & 4.97 & 4.97 & 4.98 & 0.99 & 0.14 & 0.14 & 0.14 & 0.14 & 0.14 & 1.00 & 1.83 & 1.76 & 1.76 & 1.76 & 1.76 & 0.96 \\
\hline $\mathrm{CaO}$ & 1.55 & 1.54 & 1.54 & 1.53 & 1.54 & 0.99 & 12.48 & 12.47 & 12.48 & 12.44 & 12.50 & 1.00 & 2.96 & 2.92 & 2.92 & 2.91 & 2.92 & 0.98 \\
\hline $\mathrm{TiO}_{2}$ & 0.29 & 0.29 & 0.29 & 0.28 & 0.29 & 0.99 & 1.1 & 1.11 & 1.10 & 1.10 & 1.11 & 1.00 & 0.68 & 0.67 & 0.67 & 0.67 & 0.67 & 0.98 \\
\hline V & 24 & 22 & 21 & 20 & 26 & 0.92 & 192 & 189 & 189 & 186 & 192 & 0.98 & 77 & 75 & 74 & 71 & 79 & 0.97 \\
\hline $\mathrm{Cr}$ & 3.6 & 7 & 8 & 5 & 10 & 2.06 & 314 & 308 & 308 & 305 & 311 & 0.98 & 43 & 46 & 47 & 43 & 48 & 1.07 \\
\hline $\mathrm{Mn}$ & 463 & 474 & 475 & 470 & 478 & 1.02 & 1239 & 1227 & 1226 & 1220 & 1234 & 0.99 & 886 & 883 & 883 & 873 & 892 & 1.00 \\
\hline $\mathrm{Fe}_{2} \mathrm{O}_{3}$ & 2.14 & 1.92 & 1.92 & 1.91 & 1.93 & 0.90 & 10.1 & 10.08 & 10.08 & 10.06 & 10.09 & 1.00 & 4.18 & 4.12 & 4.12 & 4.11 & 4.12 & 0.98 \\
\hline Co & 3.4 & 5 & 4 & 3 & 6 & 1.32 & 49 & 49 & 49 & 48 & 50 & 1.00 & 15 & 17 & 17 & 15 & 18 & 1.09 \\
\hline $\mathrm{Ni}$ & 2.3 & 5 & 5 & 5 & 6 & 2.30 & 115 & 120 & 120 & 119 & 121 & 1.04 & 22 & 24 & 24 & 23 & 24 & 1.08 \\
\hline $\mathrm{Cu}$ & 3.2 & 0 & 0 & 0 & 0 & & 59 & 62 & 62 & 60 & 64 & 1.05 & 23 & 46 & 45 & 45 & 46 & 2.02 \\
\hline $\mathrm{Zn}$ & 28 & 23 & 23 & 22 & 24 & 0.82 & 60 & 59 & 59 & 58 & 60 & 0.99 & 780 & 803 & 804 & 799 & 806 & 1.03 \\
\hline $\mathrm{Rb}$ & 466 & 462 & 462 & 460 & 463 & 0.99 & 1 & 18 & 18 & 18 & 18 & 18.00 & 63 & 48 & 48 & 46 & 50 & 0.76 \\
\hline $\mathrm{Sr}$ & 106 & 117 & 117 & 116 & 119 & 1.11 & 280 & 271 & 271 & 269 & 272 & 0.97 & 236 & 228 & 228 & 226 & 229 & 0.96 \\
\hline Y & 62 & 70 & 70 & 69 & 71 & 1.13 & 11 & 11 & 12 & 10 & 12 & 1.02 & 16 & 14 & 14 & 14 & 15 & 0.89 \\
\hline $\mathrm{Zr}$ & 167 & 173 & 173 & 172 & 174 & 1.03 & 39 & 36 & 36 & 36 & 37 & 0.93 & 184 & 171 & 171 & 170 & 173 & 0.93 \\
\hline $\mathrm{Ba}$ & 343 & 325 & 329 & 306 & 336 & 0.95 & 148 & 150 & 151 & 140 & 158 & 1.01 & 437 & 426 & 426 & 412 & 436 & 0.97 \\
\hline $\mathrm{La}$ & 54 & 53 & 55 & 50 & 56 & 0.99 & 3 & 6 & 5 & 4 & 8 & 2.14 & 27 & 26 & 26 & 24 & 29 & 0.97 \\
\hline $\mathrm{Ce}$ & 108 & 105 & 104 & 101 & 109 & 0.97 & 7 & 5 & 3 & 1 & 11 & 0.68 & 54 & 54 & 54 & 48 & 58 & 0.99 \\
\hline $\mathrm{Nd}$ & 47 & 46 & 46 & 43 & 50 & 0.98 & 6 & 7 & 6 & 6 & 9 & 1.27 & 22 & 24 & 23 & 22 & 25 & 1.07 \\
\hline $\mathrm{Pb}$ & 31 & 20 & 20 & 20 & 21 & 0.66 & 3 & 10 & 10 & 10 & 10 & 4.00 & 555 & 530 & 530 & 529 & 532 & 0.96 \\
\hline Th & 54 & 53 & 53 & 53 & 54 & 0.98 & 0.05 & 1 & 1 & & & 20.00 & 7 & 7 & 7 & 6 & 7 & 1.00 \\
\hline
\end{tabular}




\begin{tabular}{|c|c|c|c|c|c|c|c|c|c|c|c|c|c|c|c|c|c|c|}
\hline & \multicolumn{6}{|c|}{ GBW07311 } & \multicolumn{6}{|c|}{ IPT 32} & \multicolumn{6}{|c|}{ Kaolin KK } \\
\hline & $x_{r e f}$ & $x_{m n}$ & $x_{m d}$ & $\operatorname{dec}_{l}$ & $d e c_{u p}$ & $x_{m n} / x_{r e f}$ & $x_{r e f}$ & $x_{m n}$ & $x_{m d}$ & $\operatorname{dec}_{l}$ & $d e c_{u p}$ & $x_{m n} / x_{r e f}$ & $x_{r e f}$ & $x_{m n}$ & $x_{m d}$ & $\operatorname{dec}_{l}$ & $d e c_{u p}$ & $x_{m n} / x_{r e f}$ \\
\hline $\mathrm{Na}_{2} \mathrm{O}$ & 0.46 & 0.47 & 0.47 & 0.46 & 0.47 & 1.02 & 0.16 & 0.20 & 0.20 & 0.19 & 0.20 & 1.22 & 0.03 & 0.06 & 0.06 & 0.06 & 0.07 & 2.13 \\
\hline $\mathrm{MgO}$ & 0.62 & 0.64 & 0.64 & 0.63 & 0.64 & 1.03 & 0.39 & 0.42 & 0.42 & 0.42 & 0.43 & 1.08 & 0.20 & 0.27 & 0.27 & 0.27 & 0.27 & 1.38 \\
\hline $\mathrm{Al}_{2} \mathrm{O}_{3}$ & 10.37 & 10.58 & 10.58 & 10.57 & 10.60 & 1.02 & 28.50 & 28.56 & 28.56 & 28.51 & 28.59 & 1.00 & 36.75 & 36.65 & 36.66 & 36.62 & 36.71 & 1.00 \\
\hline $\mathrm{SiO}_{2}$ & 76.25 & 76.11 & 76.10 & 76.04 & 76.19 & 1.00 & 51.80 & 51.68 & 51.66 & 51.57 & 51.78 & 1.00 & 47.05 & 46.57 & 46.59 & 46.47 & 46.67 & 0.99 \\
\hline $\mathrm{P}_{2} \mathrm{O}_{5}$ & & 0.05 & 0.05 & 0.05 & 0.05 & & 0.13 & 0.11 & 0.11 & 0.11 & 0.11 & 0.82 & 0.09 & 0.08 & 0.08 & 0.08 & 0.08 & 0.88 \\
\hline $\mathrm{K}_{2} \mathrm{O}$ & 3.28 & 3.14 & 3.14 & 3.14 & 3.15 & 0.96 & 0.80 & 0.84 & 0.84 & 0.84 & 0.84 & 1.05 & 1.07 & 1.14 & 1.14 & 1.14 & 1.14 & 1.07 \\
\hline $\mathrm{CaO}$ & 0.47 & 0.47 & 0.47 & 0.47 & 0.47 & 1.00 & 0.17 & 0.19 & 0.19 & 0.19 & 0.19 & 1.12 & 0.26 & 0.28 & 0.28 & 0.28 & 0.28 & 1.08 \\
\hline $\mathrm{TiO}_{2}$ & 0.35 & 0.35 & 0.35 & 0.35 & 0.36 & 1.01 & 1.49 & 1.52 & 1.52 & 1.51 & 1.52 & 1.02 & 0.17 & 0.18 & 0.18 & 0.18 & 0.19 & 1.11 \\
\hline $\mathrm{V}$ & 47 & 45 & 46 & 41 & 47 & 0.95 & & 88 & 89 & 83 & 92 & & 19 & 20 & 20 & 16 & 23 & 1.04 \\
\hline $\mathrm{Cr}$ & 40 & 40 & 40 & 36 & 43 & 0.99 & & 58 & 59 & 57 & 60 & & 10 & 12 & 13 & 9 & 16 & 1.22 \\
\hline $\mathrm{Mn}$ & 2490 & 2569 & 2571 & 2558 & 2579 & 1.03 & & 115 & 115 & 107 & 122 & & 116 & 112 & 111 & 107 & 119 & 0.97 \\
\hline $\mathrm{Fe}_{2} \mathrm{O}_{3}$ & 4.39 & 4.28 & 4.28 & 4.27 & 4.29 & 0.98 & 3.46 & 3.43 & 3.43 & 3.42 & 3.44 & 0.99 & 0.98 & 0.98 & 0.98 & 0.97 & 0.98 & 1.00 \\
\hline $\mathrm{Co}$ & 9 & 9 & 9 & 7 & 10 & 1.04 & & 6 & 6 & 5 & 7 & & 3 & 3 & 3 & 2 & 3 & 1.00 \\
\hline $\mathrm{Ni}$ & 14 & 15 & 15 & 14 & 15 & 1.02 & & 10 & 10 & 9 & 11 & & 8 & 2 & 2 & 2 & 3 & 0.31 \\
\hline $\mathrm{Cu}$ & 79 & 83 & 84 & 82 & 84 & 1.05 & & 16 & 16 & 14 & 17 & & 10 & 65 & 65 & 64 & 66 & 6.76 \\
\hline $\mathrm{Zn}$ & 373 & 385 & 385 & 383 & 387 & 1.03 & & 55 & 55 & 54 & 56 & & 48 & 47 & 47 & 47 & 49 & 0.99 \\
\hline $\mathrm{Rb}$ & 408 & 358 & 359 & 355 & 360 & 0.88 & & 30 & 31 & 29 & 32 & & 164 & 160 & 160 & 157 & 161 & 0.97 \\
\hline $\mathrm{Sr}$ & 29 & 30 & 30 & 28 & 31 & 1.02 & & 86 & 86 & 85 & 86 & & 75 & 79 & 80 & 78 & 80 & 1.06 \\
\hline $\mathrm{Y}$ & 43 & 41 & 41 & 40 & 42 & 0.95 & & 27 & 27 & 26 & 27 & & 31 & 22 & 22 & 21 & 22 & 0.71 \\
\hline $\mathrm{Zr}$ & 153 & 145 & 145 & 143 & 147 & 0.95 & & 660 & 660 & 658 & 661 & & 74 & 76 & 76 & 74 & 76 & 1.02 \\
\hline $\mathrm{Ba}$ & 260 & 252 & 249 & 239 & 265 & 0.97 & & 350 & 352 & 327 & 363 & & 172 & 176 & 176 & 170 & 182 & 1.02 \\
\hline $\mathrm{La}$ & 30 & 28 & 28 & 26 & 30 & 0.93 & & 97 & 97 & 92 & 100 & & 51 & 57 & 57 & 54 & 60 & 1.13 \\
\hline $\mathrm{Ce}$ & 58 & 56 & 56 & 52 & 60 & 0.96 & & 143 & 143 & 139 & 148 & & 154 & 131 & 132 & 128 & 135 & 0.85 \\
\hline $\mathrm{Nd}$ & 27 & 28 & 29 & 27 & 30 & 1.05 & & 64 & 65 & 61 & 67 & & 47 & 64 & 64 & 63 & 66 & 1.36 \\
\hline $\mathrm{Pb}$ & 636 & 622 & 622 & 621 & 624 & 0.98 & & 64 & 64 & 63 & 65 & & 116 & 138 & 138 & 137 & 138 & 1.19 \\
\hline Th & 23 & 32 & 33 & 31 & 33 & 1.39 & & 30 & 31 & 29 & 31 & & 22 & 25 & 25 & 24 & 26 & 1.16 \\
\hline
\end{tabular}

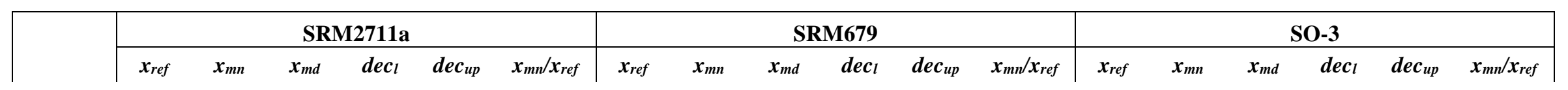




\begin{tabular}{|c|c|c|c|c|c|c|c|c|c|c|c|c|c|c|c|c|c|c|}
\hline $\mathrm{Na}_{2} \mathrm{O}$ & 1.62 & 1.67 & 1.67 & 1.66 & 1.67 & 1.03 & 0.18 & 0.21 & 0.21 & 0.21 & 0.21 & 1.20 & 1.00 & 0.97 & 0.96 & 0.96 & 0.97 & 0.97 \\
\hline $\mathrm{MgO}$ & 1.77 & 1.72 & 1.72 & 1.71 & 1.72 & 0.97 & 1.25 & 1.31 & 1.31 & 1.31 & 1.32 & 1.05 & 8.26 & 8.43 & 8.43 & 8.41 & 8.45 & 1.02 \\
\hline $\mathrm{Al}_{2} \mathrm{O}_{3}$ & 12.70 & 12.73 & 12.74 & 12.72 & 12.74 & 1.00 & 20.80 & 20.79 & 20.80 & 20.76 & 20.82 & 1.00 & 5.78 & 5.71 & 5.71 & 5.69 & 5.71 & 0.99 \\
\hline $\mathrm{SiO}_{2}$ & 67.17 & 66.34 & 66.37 & 66.26 & 66.41 & 0.99 & 52.07 & 52.14 & 52.14 & 52.08 & 52.19 & 1.00 & 33.93 & 33.77 & 33.76 & 33.71 & 33.84 & 1.00 \\
\hline $\mathrm{P}_{2} \mathrm{O}_{5}$ & & 0.19 & 0.20 & 0.19 & 0.20 & & & 0.16 & 0.16 & 0.16 & 0.16 & & & 0.10 & 0.10 & 0.10 & 0.11 & \\
\hline $\mathrm{K}_{2} \mathrm{O}$ & 3.05 & 3.06 & 3.06 & 3.06 & 3.06 & 1.00 & 2.93 & 2.91 & 2.91 & 2.91 & 2.92 & 0.99 & 1.40 & 1.34 & 1.34 & 1.34 & 1.34 & 0.96 \\
\hline $\mathrm{CaO}$ & 3.39 & 3.39 & 3.39 & 3.39 & 3.40 & 1.00 & 0.23 & 0.24 & 0.24 & 0.24 & 0.25 & 1.07 & 20.47 & 20.57 & 20.57 & 20.52 & 20.61 & 1.00 \\
\hline $\mathrm{TiO}_{2}$ & 0.53 & 0.53 & 0.53 & 0.53 & 0.54 & 1.01 & 0.96 & 0.98 & 0.98 & 0.98 & 0.98 & 1.02 & 0.33 & 0.32 & 0.32 & 0.32 & 0.32 & 0.97 \\
\hline V & 81 & 83 & 83 & 80 & 86 & 1.02 & & 164 & 164 & 160 & 168 & & 38 & 34 & 35 & 33 & 35 & 0.90 \\
\hline $\mathrm{Cr}$ & 52 & 120 & 119 & 117 & 122 & 2.28 & 110 & 108 & 109 & 103 & 111 & 0.98 & 26 & 28 & 28 & 26 & 31 & 1.09 \\
\hline $\mathrm{Mn}$ & 675 & 692 & 693 & 684 & 699 & 1.03 & 1730 & 1784 & 1787 & 1774 & 1792 & 1.03 & 520 & 538 & 536 & 532 & 547 & 1.03 \\
\hline $\mathrm{Fe}_{2} \mathrm{O}_{3}$ & 4.03 & 4.12 & 4.12 & 4.11 & 4.13 & 1.02 & 12.94 & 13.03 & 13.04 & 13.01 & 13.05 & 1.01 & 2.16 & 2.16 & 2.16 & 2.16 & 2.17 & 1.00 \\
\hline Co & 10 & 11 & 11 & 10 & 12 & 1.08 & 26 & 25 & 25 & 24 & 27 & 0.97 & 8 & 5 & 5 & 4 & 7 & 0.65 \\
\hline $\mathrm{Ni}$ & 22 & 54 & 54 & 53 & 55 & 2.48 & & 63 & 63 & 62 & 63 & & 16 & 11 & 11 & 10 & 11 & 0.66 \\
\hline $\mathrm{Cu}$ & 140 & 133 & 133 & 132 & 134 & 0.95 & & 37 & 37 & 35 & 39 & & 17 & 21 & 21 & 20 & 22 & 1.24 \\
\hline $\mathrm{Zn}$ & 414 & 417 & 417 & 416 & 419 & 1.01 & 150 & 117 & 117 & 116 & 118 & 0.78 & 52 & 50 & 50 & 49 & 50 & 0.95 \\
\hline $\mathrm{Rb}$ & 120 & 118 & 118 & 117 & 119 & 0.98 & 190 & 185 & 185 & 184 & 187 & 0.97 & 39 & 32 & 32 & 31 & 34 & 0.83 \\
\hline $\mathrm{Sr}$ & 242 & 234 & 235 & 234 & 235 & 0.97 & 73 & 80 & 80 & 78 & 82 & 1.09 & 217 & 219 & 220 & 218 & 220 & 1.01 \\
\hline Y & & 32 & 32 & 32 & 33 & & & 40 & 40 & 40 & 41 & & & 16 & 16 & 16 & 16 & \\
\hline $\mathrm{Zr}$ & & 327 & 327 & 325 & 329 & & & 155 & 155 & 153 & 156 & & & 170 & 170 & 169 & 171 & \\
\hline $\mathrm{Ba}$ & 730 & 718 & 712 & 707 & 733 & 0.98 & 432 & 470 & 469 & 456 & 484 & 1.09 & 296 & 278 & 282 & 267 & 286 & 0.94 \\
\hline $\mathrm{La}$ & 38 & 42 & 42 & 40 & 45 & 1.11 & & 52 & 52 & 50 & 55 & & & 17 & 18 & 13 & 20 & \\
\hline $\mathrm{Ce}$ & 70 & 74 & 75 & 70 & 79 & 1.06 & 105 & 101 & 101 & 96 & 106 & 0.96 & & 33 & 33 & 30 & 37 & \\
\hline $\mathrm{Nd}$ & 29 & 34 & 34 & 30 & 37 & 1.16 & & 46 & 46 & 45 & 49 & & & 19 & 19 & 17 & 22 & \\
\hline $\mathrm{Pb}$ & 1400 & 1570 & 1569 & 1567 & 1574 & 1.12 & & 26 & 26 & 25 & 27 & & 14 & 15 & 15 & 14 & 16 & 1.10 \\
\hline Th & 15 & 18 & 18 & 17 & 20 & 1.22 & 14 & 16 & 16 & 15 & 17 & 1.14 & & 3 & 3 & 3 & 4 & \\
\hline
\end{tabular}

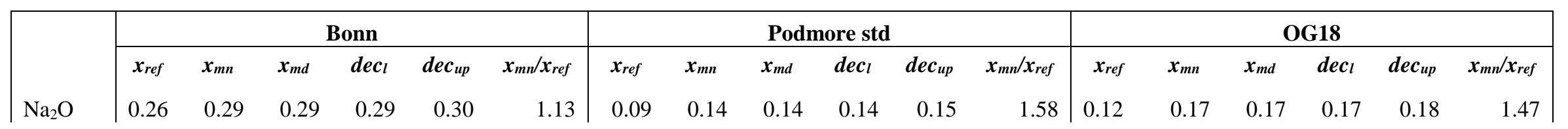




\begin{tabular}{|c|c|c|c|c|c|c|c|c|c|c|c|c|c|c|c|c|c|c|}
\hline $\mathrm{MgO}$ & 0.5 & 0.54 & 0.54 & 0.54 & 0.55 & 1.09 & & 0.99 & 0.99 & 0.99 & 1.00 & & & 0.48 & 0.48 & 0.48 & 0.49 & \\
\hline $\mathrm{Al}_{2} \mathrm{O}_{3}$ & 30.8 & 32.39 & 32.39 & 32.35 & 32.43 & 1.05 & 21.62 & 22.20 & 22.20 & 22.18 & 22.21 & 1.03 & 30.74 & 32.38 & 32.38 & 32.34 & 32.43 & 1.05 \\
\hline $\mathrm{SiO}_{2}$ & & 58.97 & 58.96 & 58.91 & 59.05 & & & 53.40 & 53.42 & 53.31 & 53.47 & & & 59.68 & 59.68 & 59.62 & 59.74 & \\
\hline $\mathrm{P}_{2} \mathrm{O}_{5}$ & & 0.07 & 0.07 & 0.07 & 0.07 & & & 0.10 & 0.10 & 0.10 & 0.10 & & & 0.09 & 0.09 & 0.09 & 0.09 & \\
\hline $\mathrm{K}_{2} \mathrm{O}$ & 1.61 & 1.54 & 1.54 & 1.54 & 1.54 & 0.96 & 1.63 & 1.46 & 1.46 & 1.46 & 1.46 & 0.90 & 1.55 & 1.58 & 1.58 & 1.57 & 1.58 & 1.02 \\
\hline $\mathrm{CaO}$ & 0.39 & 0.28 & 0.28 & 0.28 & 0.28 & 0.72 & 2.55 & 2.59 & 2.59 & 2.58 & 2.59 & 1.01 & 0.11 & 0.17 & 0.17 & 0.17 & 0.17 & 1.50 \\
\hline $\mathrm{TiO}_{2}$ & 1.3 & 1.51 & 1.51 & 1.51 & 1.52 & 1.16 & 1.13 & 1.21 & 1.21 & 1.21 & 1.22 & 1.07 & 2.26 & 2.19 & 2.19 & 2.19 & 2.20 & 0.97 \\
\hline $\mathrm{V}$ & & 168 & 168 & 165 & 172 & & 152 & 168 & 168 & 165 & 171 & 1.10 & 192 & 184 & 183 & 180 & 187 & 0.95 \\
\hline $\mathrm{Cr}$ & 115 & 127 & 127 & 124 & 129 & 1.10 & 121 & 115 & 117 & 112 & 118 & 0.95 & 177 & 173 & 173 & 170 & 177 & 0.98 \\
\hline $\mathrm{Mn}$ & 50 & 52 & 51 & 47 & 58 & 1.03 & 405 & 410 & 410 & 404 & 415 & 1.01 & 30 & 22 & 23 & 13 & 29 & 0.75 \\
\hline $\mathrm{Fe}_{2} \mathrm{O}_{3}$ & 1.66 & 1.61 & 1.61 & 1.61 & 1.61 & 0.97 & 7.84 & 7.45 & 7.45 & 7.44 & 7.45 & 0.95 & 1.41 & 1.48 & 1.48 & 1.48 & 1.49 & 1.05 \\
\hline Co & 22 & 20 & 20 & 19 & 21 & 0.90 & 20 & 19 & 19 & 18 & 20 & 0.95 & 5 & 8 & 7 & 7 & 9 & 1.58 \\
\hline $\mathrm{Ni}$ & 419 & 324 & 325 & 323 & 325 & 0.77 & 69 & 55 & 55 & 55 & 55 & 0.80 & 44 & 32 & 33 & 32 & 33 & 0.74 \\
\hline $\mathrm{Cu}$ & 72 & 37 & 37 & 36 & 39 & 0.52 & & 26 & 26 & 25 & 28 & & & 31 & 31 & 29 & 31 & \\
\hline $\mathrm{Zn}$ & 92 & 79 & 79 & 78 & 80 & 0.86 & 80 & 60 & 60 & 59 & 61 & 0.75 & 56 & 43 & 44 & 42 & 44 & 0.77 \\
\hline $\mathrm{Rb}$ & 75 & 73 & 73 & 72 & 74 & 0.97 & 85 & 79 & 79 & 76 & 81 & 0.93 & 100 & 98 & 98 & 96 & 100 & 0.98 \\
\hline $\mathrm{Sr}$ & 116 & 120 & 120 & 118 & 121 & 1.04 & & 105 & 105 & 104 & 106 & & 586 & 567 & 567 & 565 & 569 & 0.97 \\
\hline $\mathrm{Y}$ & & 28 & 28 & 28 & 29 & & & 34 & 34 & 33 & 34 & & & 40 & 41 & 40 & 41 & \\
\hline $\mathrm{Zr}$ & 116 & 209 & 209 & 208 & 210 & 1.80 & & 198 & 198 & 196 & 199 & & 300 & 424 & 424 & 423 & 425 & 1.41 \\
\hline $\mathrm{Ba}$ & 674 & 690 & 692 & 680 & 705 & 1.02 & & 398 & 396 & 387 & 413 & & 367 & 359 & 356 & 346 & 375 & 0.98 \\
\hline $\mathrm{La}$ & 49 & 49 & 49 & 46 & 51 & 1.00 & 42 & 42 & 42 & 41 & 44 & 1.00 & 62 & 57 & 57 & 55 & 60 & 0.93 \\
\hline $\mathrm{Ce}$ & 87 & 80 & 81 & 75 & 84 & 0.92 & 80 & 81 & 81 & 77 & 86 & 1.01 & 109 & 107 & 107 & 102 & 112 & 0.98 \\
\hline $\mathrm{Nd}$ & 36 & 38 & 37 & 36 & 40 & 1.06 & & 38 & 38 & 37 & 40 & & 39 & 42 & 42 & 39 & 43 & 1.08 \\
\hline $\mathrm{Pb}$ & & 33 & 33 & 33 & 34 & & & 37 & 37 & 35 & 37 & & & 55 & 56 & 54 & 56 & \\
\hline Th & 16 & 15 & 14 & 14 & 15 & 0.93 & 14 & 13 & 13 & 11 & 13 & 0.89 & 32 & 31 & 31 & 31 & 32 & 0.97 \\
\hline
\end{tabular}

\begin{tabular}{|c|c|c|c|c|c|c|c|c|c|c|c|c|c|c|c|c|c|c|c|c|}
\hline & \multicolumn{6}{|c|}{ NOR18 } & \multicolumn{6}{|c|}{ TF18 } & \multicolumn{6}{|c|}{ Pikermi } & \multirow{2}{*}{$\begin{array}{c}\text { mean of } \\
\mathbf{X m n}_{\mathrm{mn}} / \mathbf{X}_{\mathrm{ref}}\end{array}$} & \multirow{2}{*}{$\begin{array}{c}\text { stdev. of } \\
\mathbf{x}_{\mathrm{mn}} / \mathbf{x}_{\text {ref }}\end{array}$} \\
\hline & $x_{r e f}$ & $x_{m n}$ & $x_{m d}$ & $\operatorname{dec}_{l}$ & $\operatorname{dec}_{u p}$ & $x_{m n} / x_{r e f}$ & $x_{r e f}$ & $x_{m n}$ & $x_{m d}$ & $\operatorname{dec}_{l}$ & $d e c_{u p}$ & $x_{m n} / x_{r e f}$ & $x_{r e f}$ & $x_{m n}$ & $x_{m d}$ & $\operatorname{dec}_{l}$ & $d e c_{u p}$ & $\begin{array}{c}x_{m n} / x_{r} \\
e f\end{array}$ & & \\
\hline $\mathrm{Na}_{2} \mathrm{O}$ & 0.19 & 0.25 & 0.25 & 0.24 & 0.25 & 1.33 & 0.77 & 0.87 & 0.87 & 0.86 & 0.88 & 1.12 & 0.78 & 0.82 & 0.82 & 0.82 & 0.83 & 1.06 & 1.22 & 0.31 \\
\hline $\mathrm{MgO}$ & & 1.64 & 1.64 & 1.63 & 1.66 & & & 0.50 & 0.50 & 0.50 & 0.50 & & 1.49 & 1.35 & 1.35 & 1.34 & 1.36 & 0.91 & 1.05 & 0.12 \\
\hline
\end{tabular}




\begin{tabular}{|c|c|c|c|c|c|c|c|c|c|c|c|c|c|c|c|c|c|c|c|c|}
\hline $\mathrm{Al}_{2} \mathrm{O}_{3}$ & 17.65 & 18.41 & 18.42 & 18.40 & 18.42 & 1.04 & 22.55 & 23.59 & 23.59 & 23.58 & 23.60 & 1.05 & 15.65 & 15.06 & 15.06 & 15.05 & 15.08 & 0.96 & 1.01 & 0.03 \\
\hline $\mathrm{SiO}_{2}$ & & 65.75 & 65.75 & 65.67 & 65.84 & & & 69.36 & 69.34 & 69.28 & 69.45 & & 39.96 & 41.72 & 41.71 & 41.68 & 41.77 & 1.04 & 1.00 & 0.02 \\
\hline $\mathrm{P}_{2} \mathrm{O}_{5}$ & & 0.09 & 0.09 & 0.09 & 0.09 & & & 0.06 & 0.06 & 0.06 & 0.06 & & 0.159 & 0.14 & 0.14 & 0.14 & 0.15 & 0.91 & 0.92 & 0.08 \\
\hline $\mathrm{K}_{2} \mathrm{O}$ & 4.21 & 4.16 & 4.16 & 4.16 & 4.17 & 0.99 & 1.54 & 1.49 & 1.49 & 1.49 & 1.49 & 0.97 & 1.85 & 1.91 & 1.91 & 1.90 & 1.91 & 1.03 & 0.99 & 0.04 \\
\hline $\mathrm{CaO}$ & 0.20 & 0.20 & 0.20 & 0.20 & 0.20 & 0.98 & 0.32 & 0.34 & 0.34 & 0.34 & 0.34 & 1.07 & 14.99 & 15.04 & 15.04 & 15.03 & 15.06 & 1.00 & 1.03 & 0.16 \\
\hline $\mathrm{TiO}_{2}$ & 0.99 & 1.09 & 1.09 & 1.09 & 1.09 & 1.10 & 1.42 & 1.34 & 1.34 & 1.34 & 1.35 & 0.94 & 0.68 & 0.76 & 0.76 & 0.75 & 0.76 & 1.11 & 1.03 & 0.06 \\
\hline V & 195 & 201 & 201 & 196 & 204 & 1.03 & 132 & 128 & 129 & 126 & 129 & 0.97 & 113 & 123 & 123 & 120 & 126 & 1.09 & 0.99 & 0.06 \\
\hline $\mathrm{Cr}$ & 91 & 83 & 83 & 80 & 88 & 0.92 & 103 & 95 & 95 & 93 & 96 & 0.92 & 135 & 146 & 146 & 143 & 148 & 1.08 & 1.19 & 0.43 \\
\hline $\mathrm{Mn}$ & 259 & 246 & 247 & 237 & 253 & 0.95 & 57 & 47 & 46 & 42 & 52 & 0.82 & 690 & 797 & 798 & 789 & 803 & 1.16 & 0.99 & 0.10 \\
\hline $\mathrm{Fe}_{2} \mathrm{O}_{3}$ & 7.32 & 7.39 & 7.39 & 7.38 & 7.40 & 1.01 & 1.49 & 1.53 & 1.53 & 1.53 & 1.53 & 1.03 & 6.88 & 6.93 & 6.93 & 6.92 & 6.95 & 1.01 & 0.99 & 0.04 \\
\hline $\mathrm{Co}$ & 23 & 23 & 23 & 22 & 24 & 1.00 & 4 & 4 & 4 & 3 & 5 & 0.91 & 24 & 23 & 23 & 22 & 24 & 0.97 & 1.03 & 0.21 \\
\hline $\mathrm{Ni}$ & 58 & 75 & 74 & 74 & 76 & 1.27 & 36 & 18 & 18 & 18 & 18 & 0.50 & 120 & 122 & 122 & 121 & 123 & 1.02 & 1.08 & 0.64 \\
\hline $\mathrm{Cu}$ & & 20 & 20 & 19 & 22 & & & 7 & 7 & 6 & 8 & & 39 & 49 & 49 & 48 & 50 & 1.27 & 1.86 & 2.03 \\
\hline $\mathrm{Zn}$ & 103 & 91 & 91 & 90 & 92 & 0.88 & 47 & 41 & 41 & 40 & 41 & 0.87 & 108 & 111 & 111 & 110 & 111 & 1.03 & 0.91 & 0.10 \\
\hline $\mathrm{Rb}$ & 181 & 178 & 178 & 177 & 179 & 0.98 & 69 & 73 & 73 & 72 & 74 & 1.05 & 94 & 89 & 89 & 87 & 90 & 0.95 & 2.16 & 4.56 \\
\hline $\mathrm{Sr}$ & 64 & 80 & 80 & 79 & 81 & 1.26 & 141 & 179 & 179 & 178 & 180 & 1.28 & 105 & 113 & 113 & 112 & 114 & 1.08 & 1.06 & 0.10 \\
\hline $\mathrm{Y}$ & & 45 & 45 & 44 & 45 & & & 32 & 32 & 32 & 33 & & 33 & 36 & 36 & 35 & 36 & 1.08 & 0.96 & 0.15 \\
\hline $\mathrm{Zr}$ & 188 & 257 & 257 & 256 & 258 & 1.37 & 241 & 345 & 346 & 343 & 347 & 1.43 & 135 & 160 & 161 & 159 & 161 & 1.18 & 1.21 & 0.29 \\
\hline $\mathrm{Ba}$ & 558 & 631 & 630 & 626 & 641 & 1.13 & 375 & 404 & 404 & 395 & 411 & 1.08 & 231 & 229 & 231 & 221 & 236 & 0.99 & 1.01 & 0.06 \\
\hline $\mathrm{La}$ & 50 & 53 & 53 & 49 & 56 & 1.05 & 47 & 47 & 46 & 44 & 50 & 0.99 & 38 & 39 & 39 & 37 & 40 & 1.02 & 1.11 & 0.33 \\
\hline $\mathrm{Ce}$ & 115 & 114 & 115 & 110 & 119 & 0.99 & 84 & 80 & 79 & 77 & 84 & 0.95 & 67 & 65 & 64 & 62 & 69 & 0.96 & 0.95 & 0.09 \\
\hline $\mathrm{Nd}$ & 43 & 51 & 50 & 49 & 52 & 1.18 & 34 & 36 & 37 & 32 & 39 & 1.07 & 39 & 35 & 35 & 32 & 38 & 0.89 & 1.11 & 0.13 \\
\hline $\mathrm{Pb}$ & & 15 & 16 & 14 & 17 & & & 39 & 40 & 38 & 40 & & 29 & 36 & 36 & 35 & 37 & 1.24 & 1.40 & 1.06 \\
\hline Th & 15 & 17 & 17 & 16 & 18 & 1.14 & 14 & 15 & 14 & 13 & 16 & 1.01 & 12 & 10 & 10 & 9 & 11 & 0.85 & 2.51 & 5.26 \\
\hline
\end{tabular}

Table 5: Summary of results of ten measurements on eight reference materials and their reference or certified values for comparison. $\mathrm{X}_{\text {ref: }}$ certified value, $\mathrm{x}_{\mathrm{mn}}$ : mean, $\mathrm{x}_{\mathrm{md}}$ : median, $\mathrm{dec}_{1}$ and $\mathrm{dec}_{\mathrm{up}}$ : lower and upper decile (in wt $\%$ for oxides and ppm for elements). Non certified values in the CRMs are given in italics, all reference materials values are non-certified. Values more than $\pm 10 \%$ off the certified values are given in bold in the ratio columns. 

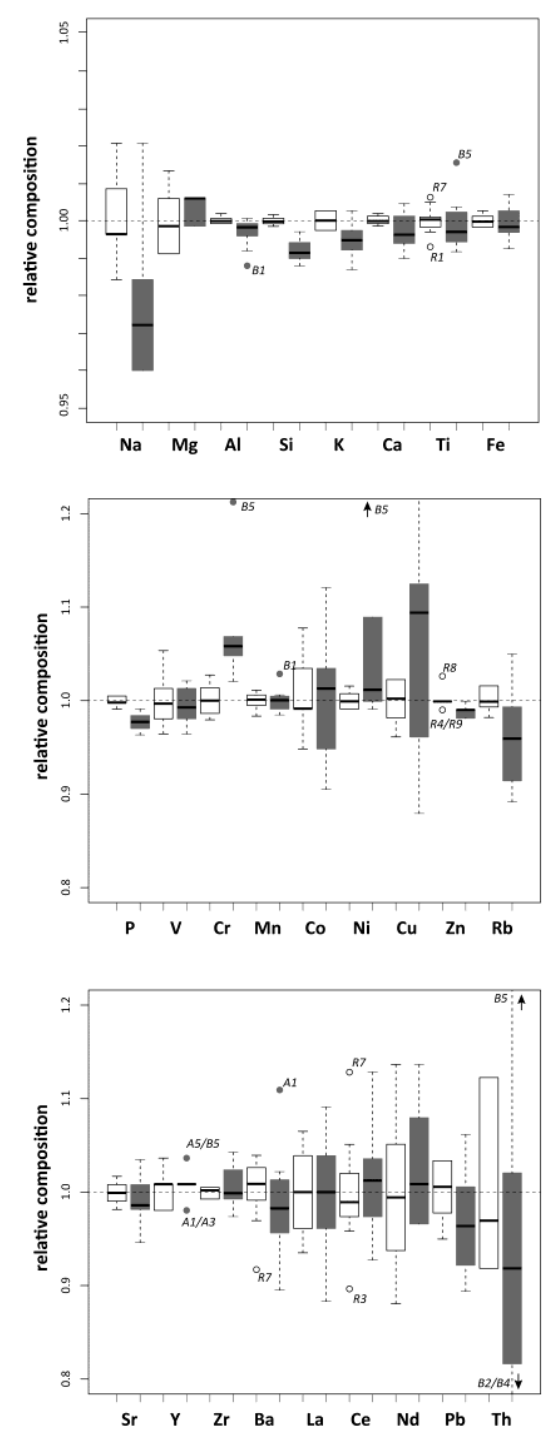

Figure 1. Boxplots (prepared by R) summarising results of ten measurements of a single bead prepared from the Pikermi clay (white boxes, data in Table 4) and single measurements of ten different beads prepared by two members of staff from the same homogenized batch of the Pikermi clay (grey boxes). The individual measured concentrations are normalised to the mean values of the repeated measurements of the single bead (Table 4). The boxes indicate the ranges between the upper quartiles (UQ) and the lower quartiles (LQ), while the whiskers include additionally values up to 1.5 times the distance from lower to upper quartile LQ $1.5^{*}(\mathrm{UQ}-\mathrm{LQ})<\mathrm{x}<\mathrm{UQ}+1.5^{*}(\mathrm{UQ}-\mathrm{LQ})$. Values outside these limits are considered as outliers and indicated as individual data points in the plots. Values marked as $\mathrm{A}$ and $\mathrm{B}$ are the correspondingly numbered beads prepared by members $\mathrm{A}$ and $\mathrm{B}$ and values with $\mathrm{R}$ are the numbered repeated measurement of the single bead. 